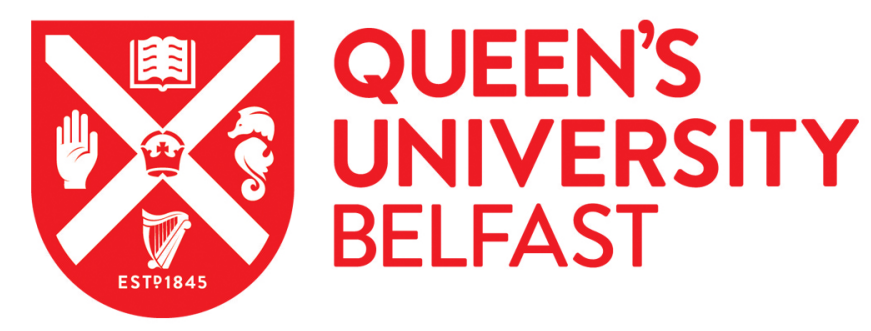

\title{
Hydrophobic deep eutectic solvents incorporating trioctylphosphine oxide: Advanced liquid extractants
}

Gilmore, M., McCourt, E. N., Connolly, F., Nockemann, P., Swadzba-Kwasny, M., \& Holbrey, J. D. (2018).

Hydrophobic deep eutectic solvents incorporating trioctylphosphine oxide: Advanced liquid extractants. ACS

Sustainable Chemistry \& Engineering, 6(12), 17323-17332. https://doi.org/10.1021/acssuschemeng.8b04843

Published in:

ACS Sustainable Chemistry \& Engineering

Document Version:

Peer reviewed version

Queen's University Belfast - Research Portal:

Link to publication record in Queen's University Belfast Research Portal

Publisher rights

Copyright 2018, ACS. This work is made available online in accordance with the publisher's policies. Please refer to any applicable terms of use of the publisher.

\section{General rights}

Copyright for the publications made accessible via the Queen's University Belfast Research Portal is retained by the author(s) and / or other copyright owners and it is a condition of accessing these publications that users recognise and abide by the legal requirements associated with these rights.

Take down policy

The Research Portal is Queen's institutional repository that provides access to Queen's research output. Every effort has been made to ensure that content in the Research Portal does not infringe any person's rights, or applicable UK laws. If you discover content in the Research Portal that you believe breaches copyright or violates any law, please contact openaccess@qub.ac.uk. 


\section{Hydrophobic deep eutectic solvents}

\section{incorporating trioctylphosphine oxide: Advanced liquid extractants}

Mark Gilmore, Eadaoin N. McCourt, Francis Connolly, Peter Nockemann, Malgorzata Swadźba-Kwaśny, ${ }^{*}$ and John D. Holbrey*

The QUILL Research Centre, School of Chemistry and Chemical Engineering, Queen's University Belfast, David Keir Building, Stranmillis Road, Belfast BT9 5AG, UK.

E-mail: m.swadzba.kwasny@qub.ac.uk; j.holbrey@qub.ac.uk 


\begin{abstract}
A low viscosity, hydrophobic eutectic solvent based on trioctylphosphine oxide (TOPO) has been developed, characterized, and it's use as an extractant demonstrated for liquid-liquid separation of uranyl nitrate from aqueous acid. This strategy of liquefying the active extracting agent as a eutectic liquid, produced liquids that contain an intrinsically concentration of TOPO ( $c a$. 80 $\mathrm{wt} \%, 1.875$ moles $\mathrm{L}^{-1}$ at $\chi_{\mathrm{TOPO}}=0.50$ ) and render the use of an organic (hydrocarbon) diluent redundant.
\end{abstract}

Keywords: Hydrophobic deep eutectic solvents; Separation, Uranyl extraction; Trioctylphosphine oxide 


\section{Introduction}

The term Deep Eutectic Solvent (DES) ${ }^{1-3}$ is most commonly used to describe low melting liquids formed by combining organic salts such as choline chloride with urea or other hydrogen-bond donor components including carboxylic acids and alcohols. DES were initially popularised ${ }^{4}$ as lower cost and more environmentally benign (greener) variants of non-volatile ionic liquids and have been used as non-aqueous electrolyte solutions, ${ }^{5}$ and media for nanoparticle and materials synthesis, ${ }^{6-9}$ solvents for catalysis ${ }^{10}$ and as vehicles for delivery of active pharmaceutical ingredients ${ }^{11,12}$ have been extensively investigated in recent years.

One area of interest in the use of DES analogs of hydrophobic ionic liquids ${ }^{13,14}$ as alternatives to hydrophobic organic solvents for organic/aqueous extractions has been less widely investigated to-date. Partially because the multiple competing coulombic and hydrogen-bonding interactions ${ }^{15-21}$ that underpin the formation of these liquids also tend to promote miscibility with water.

The first hydrophobic DES, reported by van Osch et al. ${ }^{22}$ in 2015, combined a carboxylic acid (to provide H-bond donor functionality) with long chain quaternary ammonium salts to enhance hydrophobicity over more usual short chain ammonium or cholinium salts. Following this strategy, other hydrophobic DES incorporating fatty acids and/or alcohols with organic salts have been described and their use for metal ion ${ }^{23}$ and natural product ${ }^{24,25}$ extractions demonstrated. However in common with ionic liquids, the coulombic interactions between the charge centers result in liquids with relatively high viscosity. This is compounded by the need to introduce large bulky alkyl substituents to impart hydrophobicity competing with hydrophilic association of typically good hydrogen bond acceptor anions present with water.

Moving away from ionic DES, which include a salt (or an ionizable amine component ${ }^{23}$ ),

Ribeiro et al. ${ }^{26}$ have shown that hydrophobic eutectic solvents could be prepared from mixtures of DL-menthol with a range of carboxylic acids and could be used as extractive solvents for caffeine, tryptophan, isophthalic acid, and vanillin from water. Compared to the more usual ionic DES, these liquids have significantly lower viscosity as a result of eliminating the coulombic charge 
interactions. The scope for formation of liquid eutectic solvents has subsequently been expanded to a range of terpenes with monocarboxylic acids ${ }^{27}$ and, interestingly, also to make use of mixtures of carboxylic acids to access eutectic liquid compositions. ${ }^{28}$

Building on previous experience using TOPO as a Lewis basic (hydrogen bond-accepting) ligand to generate liquid coordination complexes ${ }^{29-31}$ with tunable Lewis acid properties we were interested in studying whether trioctylphosphine oxide (TOPO) could be used as a hydrogen-bond accepting component to produce DES and whether a liquid DES formed in this way could be used as an extractant phase containing high phosphine oxide concentrations.

Trioctylphosphine oxide (TOPO) has many applications as a capping agent for the production of quantum confined nanomaterials. ${ }^{32-36}$ and as an extractant ${ }^{37}$ for metal ions and organic acids $^{38-41}$ and phenolic compounds. ${ }^{42-44}$ However, an issue with TOPO is its relatively low solubility in hydrocarbon solvents that are the choice for aqueous-organic liquid-liquid extraction processes. One approach to address this is the use of alternative phosphine oxide formulations, such as Cyanex 923. ${ }^{44,45}$ This is a mixture of trialkylphosphine oxides containing hexyl and octyl groups that is a liquid ( $\mathrm{mp}-5$ to $0{ }^{\circ} \mathrm{C}$ ) and is completely miscible with common industrial diluents (such as kerosene) allowing higher concentrations of extractant to be achieved than with TOPO.
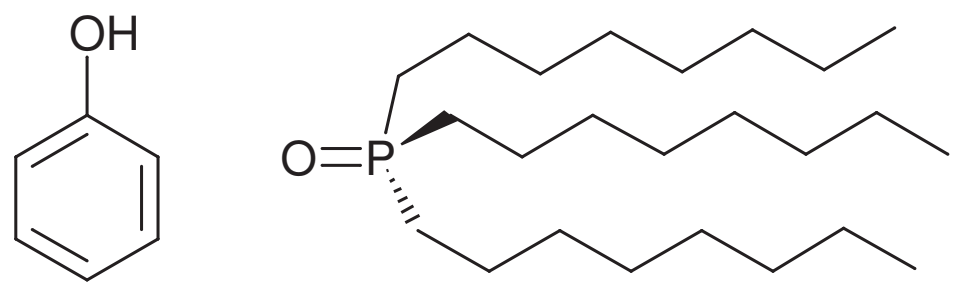

Figure 1: Structure of phenol (left) and TOPO (right).

To our knowledge, TOPO has never been transformed into an ambient temperature DES and we reasoned that a DES formed from TOPO would contain a high phosphine oxide concentration overcoming some of the challenges faced by the choices of diluent, viz. limiting solubility in non-hazardous solvents such as odorless kerosene or high solubility in hazardous solvents such as dichloromethane or benzene. Here we report the formation of an ambient temperature hydrophobic 
eutectic liquid between TOPO and phenol, as a model hydrogen-bond donor, (Figure 1) and the applicability of the system to metal extraction is demonstrated for the removal of uranyl $\left(\left[\mathrm{UO}_{2}\right]^{2+}\right)$ ions from aqueous nitric acid.

\section{Experimental Section}

Trioctylphosphine oxide (TOPO) was kindly provided by Solvay with a purity $>97 \%$, phenol (99.5\%) was purchased from Acros Organics. TOPO:phenol mixtures were prepared by combining appropriate mole fractions of each component in a minimum quantity of methanol, which was then stirred $(500 \mathrm{rpm})$ until a homogenous, colorless liquid was formed. Methanol was then removed by evaporation in vacuo $\left(3\right.$ days, $50{ }^{\circ} \mathrm{C}, 10^{-2}$ bar) and then allowed to cool to ambient temperature yielding colorless solids $\left(\chi_{\mathrm{TOPO}}>0.6\right)$ or liquids $\left(\chi_{\mathrm{TOPO}}<0.6\right)$. Materials were stored under an inert atmosphere until used. Composition and purity of the resulting mixtures was confirmed using NMR (Bruker $400 \mathrm{MHz}$ ) and FT-IR (PerkinElmer Spectrum 100) spectroscopy.

${ }^{31} \mathrm{P}$ NMR spectra were recorded on a Bruker Avance DPX $400 \mathrm{MHz}$ spectrometer at $162 \mathrm{MHz}$ using neat liquid samples. A DMSO-filled, sealed capillary was used as an external lock and stability between measurements was confirmed from the invariance of the chemical shift from trace impurities at $-0.72 \pm 0.13 \mathrm{ppm}$. Further phosphorous-containing impurities were observed in the supplied TOPO sample, observed as singlet signals at 48.48, 48.78, 51.9, 53.44 ppm compared to the main TOPO signal at $49.1 \mathrm{ppm}$ for the $\chi_{\mathrm{TOPO}}=0.60$ liquid. The ${ }^{31} \mathrm{P}$ signals for each of these trace contaminants varied with $\chi_{\mathrm{TOPO}}$ along with the signal from TOPO as described in the Results and Discussion section.

Densities were measured using a Mettler Toledo DM40 density meter over the temperature range 25-90 ${ }^{\circ} \mathrm{C}$. Viscosity was determined using a Bohlin Gemini cone and plate rheometer (TOPO:phenol, $\chi_{\text {TOPO }}=0.33$ ) between $20-90{ }^{\circ} \mathrm{C}$, and using an Anton Paar AMVn rolling ball viscometer (TOPO:phenol, $\left.\chi_{\mathrm{TOPO}}=0.50\right)$ at $20,25,40,50$, and $60{ }^{\circ} \mathrm{C}$. Water content was measured using a Mettler Toledo C30S coulometric KF titrator, in each case, the initial water content 
was below the limit of quantification the titrator, and characteristic signals attributable to water were not observed in the ${ }^{1} \mathrm{H}$ NMR or FT-IR spectra of the neat $\chi_{\mathrm{TOPO}}=0.50$ liquid.

\section{TOPO/Phenol solid-liquid phase diagram.}

Upper limits for thermal stability of the liquids were measured in the dynamic heating regime using a TA Instruments Q5000 TGA instrument under nitrogen atmosphere. The phase diagram was determined both by visual inspection and by differential scanning calorimetry (DSC). DSC measurements were performed using a TA instruments DSC Q2000 fitted with RCS 90 cooling system. Samples were loaded into Tzero aluminum pans and the accurate mass recorded $( \pm$ $0.0002 \mathrm{~g}$ ) in a glovebox under an argon dry atmosphere and then sealed using Tzero hermetic lids before removal and transfer to the DSC. Measurements were taken over three heating/cooling cycles across the temperature range -90 to $+70{ }^{\circ} \mathrm{C}$, with a cooling rate of $5{ }^{\circ} \mathrm{C} \mathrm{min}^{-1}$ and a heating rate of $1{ }^{\circ} \mathrm{C} \mathrm{min}-1$. Between heating and cooling runs, samples were held isothermally for $15 \mathrm{~min}$.

Visual determination of the solid-liquid equilibrium phase behaviour was made as a function of temperature using samples sealed in a thermostated Pyrex glass solid-liquid equilibrium cell containing a magnetic stir bar. The cell was then inserted in a thermostated ethanol bath and stirred $(400 \mathrm{rpm})$ and cooled to around $-50{ }^{\circ} \mathrm{C}$ by addition of liquid nitrogen. After holding at this temperature for 15 min samples were then allowed to warm to $-10{ }^{\circ} \mathrm{C}$ at a rate of approx. 1-2 ${ }^{\circ} \mathrm{C} \min ^{-1}$. Samples with $\chi_{\text {TOPO }}$ between $0.2-0.4$ exhibited melting of the quenched glasses

around $-35{ }^{\circ} \mathrm{C}$, whereas the remainder of the samples (high and low $\chi_{\mathrm{TOPO}}$ ) remained as solids over this temperature range. Above $c a .-10{ }^{\circ} \mathrm{C}$, temperature was controlled by a circulating Julabo R32, and samples were held for 20 min.at each set-point to ensure equilibrium.

Temperatures were measured using an insulated wire miniature type $\mathrm{K}$ thermocouple model 5SC coupled with a HH802U thermocouple thermometer, with an expected measurement uncertainty of pm $1.5{ }^{\circ} \mathrm{C}$. The measurement uncertainty resulting from the visual observation of the phase transitions is expected to be greater than the instrumental error. The melting points were recorded as the temperature at which a colorless homogenous liquid was formed in the cell. Glass 
transitions for the non-crystalline mixtures $\left(\chi_{\text {TOPO }}\right.$ between $\left.0.2-0.4\right)$ were defined from the pour points, the lowest temperature at which motion of the stir-bar was possible in the increasingly viscous liquids on cooling. No $\mathrm{T}_{\mathrm{g}}$ transitions were observed in the DSC for these samples on cooling to $-90{ }^{\circ} \mathrm{C}$. All measurements were carried out in duplicate, with reproducibility to within $1{ }^{\circ} \mathrm{C}$.

\section{Phenol and TOPO leaching to aqueous in $1 / /$ mixtures.}

Leaching of phenol into aqueous hydrochloric acid from the $\chi_{\mathrm{TOPO}}=0.50$ TOPO:phenol eutectic liquid was determined at room temperature by combining equal amounts (w/w) of the TOPO:phenol sample and aqueous acid $(0.00-3.00 \mathrm{M} \mathrm{HCl})$ in a vial which was shaken on a Stuart scientific flask shaker SF1 for $30 \mathrm{~min}$ and the left for $18 \mathrm{~h}$ to allow complete equilibration and separation of the two layers. The phenol content of the aqueous phase was then analyzed using UV/Vis spectroscopy (Agilent Technologies Cary 60 UV-Vis Spectrophotometer) with the concentration

of leached phenol determined by comparison of the absorbance at $\lambda_{\max }=270 \mathrm{~nm}$ to a standard calibration response determined for aqueous phenol.

\section{Liquid-liquid extraction of uranyl $\left(\left[\mathrm{UO}_{2}\right]^{2+}\right)$ ions from aqueous acid with TOPO:phenol eu- tectic liquids.}

All aqueous solutions were prepared with deionized water, purified with a Barnsted deionization system and polished to $18.3 \mathrm{M} \Omega \mathrm{cm}^{-1}$. Aqueous solutions of $\mathrm{HNO}_{3}$ were prepared as molar concentrations between $0.01-3.00 \mathrm{M}$ by transferring a known amount of material to a volumetric flask and diluting to the specified volume with deionized water. Uranyl solutions in water and in nitric acid were prepared by addition of uranyl nitrate hexahydrate to the standard acidic stock solutions to $250 \mathrm{ppm}\left(6.34 \times 10^{-4} \mathrm{M}\right)$ and, in one case, with $2350 \mathrm{ppm}\left(5.96 \times 10^{-3} \mathrm{M}\right)\left[\mathrm{UO}_{2}\right]^{2+}$ in $1 \mathrm{M} \mathrm{HNO}_{3}(\mathrm{aq})$ to examine the effects of uranyl concentration on extraction efficiency.

For uranyl extraction measurements, performed at ambient temperature $\left(c a .20-25^{\circ} \mathrm{C}\right), 1 \mathrm{~cm}^{3}$, samples of TOPO:phenol $\left(\chi_{\mathrm{TOPO}}=0.5\right)$ pre-equilibrated against the appropriate concentration aqueous nitric acid solution, were contacted with $1 \mathrm{~cm}^{3}$ of an acidic $250 \mathrm{ppm}$ uranyl nitrate solution 
in a $10 \mathrm{~cm}^{3}$ screw top glass vial and mixed for 10 min using a wrist-action shaker (Burrell, model 75). After mixing, the samples were centrifuged (2000 G, 2 min) and the aqueous raffinate phase separated from the DES. The residual uranium concentration in the raffinate (aqueous phase) was determined by UV/Vis spectroscopy (Agilent Technologies Cary 60 UV-Vis Spectrophotometer) after addition of 2-(5-bromo-2-pyridylazo)-5-(diethylamino)phenol (Br-PADAP) to the sample as a spectroscopic probe. ${ }^{46}$ All measurements were performed in duplicate and gave reproducible results.

Distribution ratios $(D)$ were calculated by difference between the initial and final uranyl concentrations in the aqueous raffinate phase using the equation:

$$
D=\left(\left[\mathrm{UO}_{2}^{2+}\right]_{\text {init }}-\left[\mathrm{UO}_{2}^{2+}\right]_{\text {final }}\right) /\left[\mathrm{UO}_{2}^{2+}\right]_{\text {final }}
$$

where $\left[\mathrm{UO}_{2}{ }^{2+}\right]_{\text {init }}$ and $\left[\mathrm{UO}_{2}{ }^{2+}\right]_{\text {final }}$ are the initial and final concentrations $\left(\mathrm{mol} \mathrm{dm}{ }^{-3}\right)$ uranyl concentration in the acidic aqueous phase.

\section{Results and Discussion}

Eutectic mixtures composed of TOPO and phenol in different molar ratios were prepared by mixing the two components with a small quantity of methanol, followed by evaporation of the solvent. It was also possible to form the liquids by grinding the two components together. Room temperature liquids were obtained over the composition range $\chi_{\mathrm{TOPO}}=0.1-0.6$ (Figure 2 ) and were colorless, free-flowing and were found to be hydrophobic, forming biphases when mixed with water.

Phenol was selected for initial examination based on its mild Brønsted acidity (and corresponding hydrogen-bond donor ability), the use of TOPO-impregnated membranes for solventless extraction and stripping of phenols from water, ${ }^{42,43}$ and the ability of phenol to form of biphasic systems with water at moderate concentrations and temperatures. ${ }^{47}$ Similarly, there was a synergistic interest in potentially forming hydrophobic eutectics with phenol to complement the application of phenol/tetraalkylammonium chloride DES for recovery of phenols from hydrocarbon oils. ${ }^{48}$ 


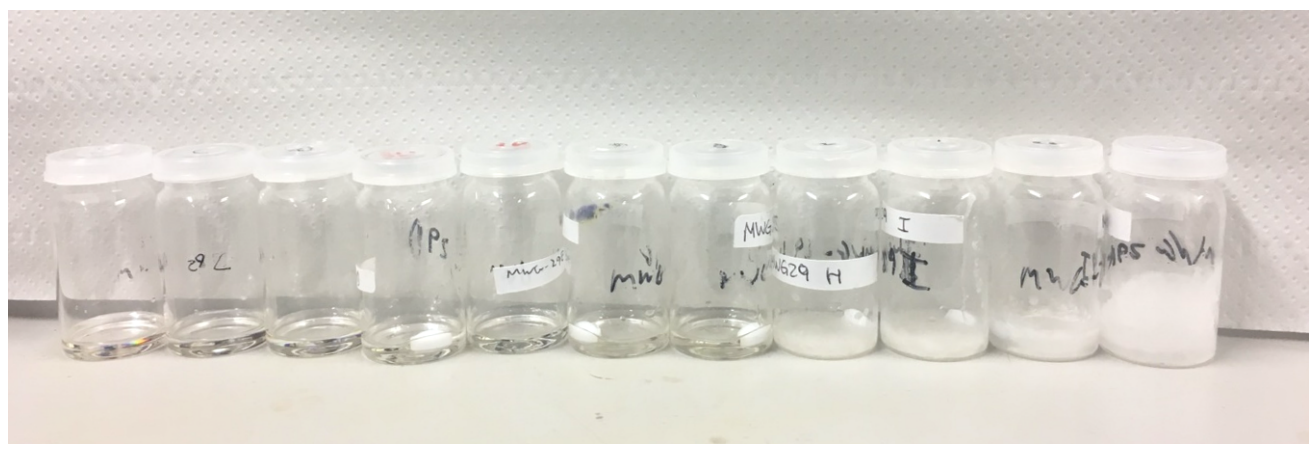

Figure 2: The appearance of TOPO:phenol mixtures of different compositions at ambient temperature (left to right, $\chi_{\mathrm{TOPO}}=0.1-0.9$ ).

The effectiveness of eutectic formation as a strategy to obtain liquefied TOPO with high phosphine oxide concentration for use in separations and extractions was then tested for liquid-liquid extraction of $\left[\mathrm{UO}_{2}\right]^{2+}$ from aqueous acid solution.

\section{Thermal stability}

TOPO:phenol mixtures retained a constant composition through heating at $50{ }^{\circ} \mathrm{C}$ to remove methanol, as confirmed by integrating and comparing ${ }^{1} \mathrm{H}$ NMR signals from phenol and TOPO components of the mixtures after drying, and were thermally stable up to $c a .90{ }^{\circ} \mathrm{C}$. Compared to the rapid mass from pure phenol, the TOPO:phenol liquid mixtures show increased stability, with two distinct mass loss events observable by TGA under dynamic heating (Figure 3). The first of these, loss of phenol through evaporation or sublimation starts around $100{ }^{\circ} \mathrm{C}$ and is complete by $200{ }^{\circ} \mathrm{C}$, on contrast to pure phenol where mass loss started at $50{ }^{\circ} \mathrm{C}$ and was complete by $130{ }^{\circ} \mathrm{C}$. In the TOPO:phenol mixtures, this is then followed by loss of TOPO above $c a .250{ }^{\circ} \mathrm{C}$. Thus the stability limit for the TOPO:phenol liquids, defined by loss of phenol from the liquids, is around $90-100{ }^{\circ} \mathrm{C}$, which is comparable with that of the archetypal choline chloride/urea DES ${ }^{9}$ where decomposition of urea is initiated from around $70{ }^{\circ} \mathrm{C}$. 


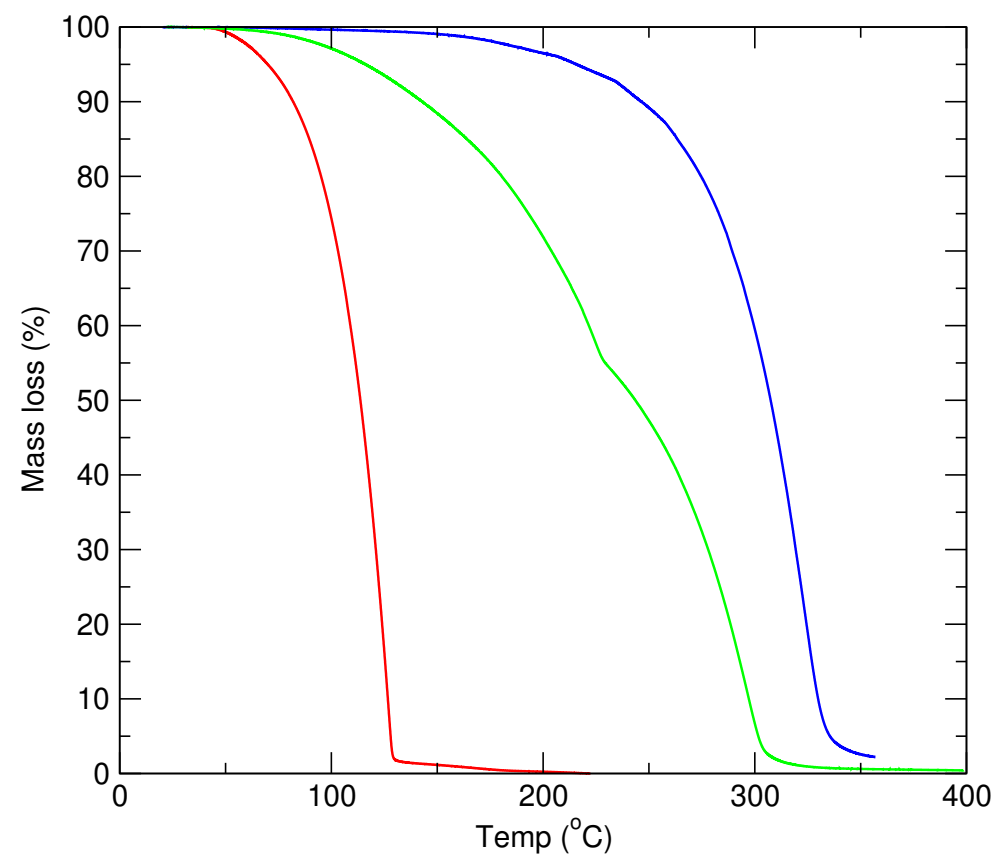

Figure 3: Mass loss profiles under dynamic TGA conditions for phenol (red), TOPO (blue) and TOPO:phenol $\left(\chi_{\text {TOPO }}=0.50\right.$, green $)$ heating at $5{ }^{\circ} \mathrm{C} \mathrm{min}^{-1}$, showing the increased thermal stability (reduced loss of phenol) in the DES compared to neat phenol.

\section{Melting point and phase composition}

A detailed investigation of the solid-liquid phase behavior of the TOPO:phenol system was made using both visual observation from samples in a solid-liquid cell and by DSC (Figure 4).

Across the intermediate composition range $\left(\chi_{\text {TOPO }}=0.20-0.40\right)$, free-flowing liquids were obtained that became progressively more viscous on cooling, eventually forming glasses that could not be poured below around $\mathrm{ca} .-34{ }^{\circ} \mathrm{C}$. The cooling and heating profiles in the DSC measurements at these compositions were essentially featureless, no crystallization of glass transition events were observable, either around the solidification points observed visually or scanning to $-80{ }^{\circ} \mathrm{C}$.

In contrast, at $\chi_{\mathrm{TOPO}}=0.10$ and from $\chi_{\mathrm{TOPO}}=0.50-1.00$, solid samples were obtained from which melting was observable both visually and from first order transitions in the DSC which were observed at comparable temperatures in the two experiments. TOPO:phenol with $\chi_{\text {TOPO }}=0.10$ extensively super-cools in the DSC, undergoing cold crystallization on heating at $c a .-50{ }^{\circ} \mathrm{C}$ and is then followed by a melting transition at $27.5^{\circ} \mathrm{C}$. This pattern was repeated over three thermal 
cycles, and shows a small depression in melting of the $\chi_{\mathrm{TOPO}}=0.10$ mixture compared to pure $\operatorname{phenol}\left(\chi_{\mathrm{TOPO}}=0.00, \mathrm{mp} 41^{\circ} \mathrm{C}\right)$.

At $\chi_{\mathrm{TOPO}}=0.50$, in the DSC, the samples super-cooled and then, on heating, undergo coldcrystallization with an extremely broad $\left(c a .20{ }^{\circ} \mathrm{C}\right)$ endothermic transition centered at $-29{ }^{\circ} \mathrm{C}$. This is followed by a sharp exotherm at $-11{ }^{\circ} \mathrm{C}\left(\Delta_{\mathrm{H}}=11.7 \mathrm{~kJ} \mathrm{~mol}^{-1}\right)$, and a much weaker broad exotherm between -10 and $6{ }^{\circ} \mathrm{C}$. In the solid-liquid cell, on heating slowly from $-40{ }^{\circ} \mathrm{C}, 1: 1$ TOPO:phenol solid was observed to melt to a slurry between from $c a$. $-10{ }^{\circ} \mathrm{C}$, and to form a single homogeneous clear liquid phase at $6{ }^{\circ} \mathrm{C}$.

Above $\chi_{\mathrm{TOPO}}=0.50$, reversible melting and freezing transitions are more readily observed in the TOPO:phenol mixtures, with all samples solidifying at temperatures above $0{ }^{\circ} \mathrm{C}$ in both the solid-liquid cell and DSC. Both the crystallization point on cooling and subsequent melting point on heating of the mixtures with systematically reduced by the introduction of phenol, and the melting transition in the DSC becomes increasingly broad, with a long trailing edge indicative of pre-melting disordering of the alkyl-chain regions as is often seen in plastic crystals, particularly from ionic liquid materials. ${ }^{49-51}$

The melting temperature (and corresponding enthalpy) of the range of TOPO:phenol compositions are shown in Table 1 and the mole fraction TOPO:phenol temperature-composition phase diagram generated from this data is shown in Figure 5. In common with many many ionic liquids and cholinium-based DES, the TOPO:phenol mixtures proved inherently difficult to crystallize ${ }^{10}$ forming glassy amorphous solids on cooling. The reduced melting points of the mixtures, coming from either high TOPO or high phenol composition can be extrapolated to a deep eutectic point in the region of $\chi_{\mathrm{TOPO}}=0.33$ (1:2 TOPO:phenol) illustrating the extensive liquid region formed by the depression in solidification point of the TOPO:phenol mixtures to $c a$. $-34{ }^{\circ} \mathrm{C}$ between $\chi_{\text {TOPO }}$ $=0.2-0.5$, compared to the melting points of the two pure starting components, TOPO $\left(\mathrm{mp} 52{ }^{\circ} \mathrm{C}\right)$ and phenol (mp $\left.42{ }^{\circ} \mathrm{C}\right)$. 
Table 1: Thermal data from DSC and observation. Temperatures were measured from the peak positions of the first order transitions in the DSC second heating cycle, and the enthalpy of melting determined from integration of the peak.

\begin{tabular}{llll}
\hline$\chi_{\mathrm{TOPO}}$ & $T_{m}(o b s)$ & $T_{m}(\mathrm{DSC}) /{ }^{\circ} \mathrm{C}$ & $E_{m} / \mathrm{kJ} \mathrm{mol}^{-1}$ \\
\hline 0.00 & 41.1 & 41.0 & \\
0.10 & 24.2 & 27.5 & 1.8 \\
0.20 & $-33.0^{a}$ & - & \\
0.30 & $-33.5^{a}$ & - & \\
0.33 & $-33.0^{a}$ & - & \\
0.40 & $-36.5^{a}$ & - & \\
0.50 & $-11^{b}$ & 5.9 & 11.7 \\
0.60 & 30.3 & 34.6 & 3.3 \\
0.67 & 36.4 & 38.1 & 6.3 \\
0.70 & 38.7 & 36.7 & 6.9 \\
0.80 & 42.8 & 46.2 & 16.6 \\
0.90 & 50.3 & 48.8 & 23.9 \\
1.00 & 51.8 & 51.9 & \\
\hline
\end{tabular}

${ }^{a}$ Solidification temperatures for $\chi_{\mathrm{TOPO}}=0.2-0.4$ were made by visual observation of the limit in pour point of the liquids: no thermal transitions were observed by DSC. ${ }^{b}$ Exothermic transition observed by DSC at $-11{ }^{\circ} \mathrm{C}$ is followed by a weak, broad event between -10 and $6{ }^{\circ} \mathrm{C}$.

Table 2: ${ }^{31} \mathrm{P}$ NMR chemical shifts $\left(\delta^{31} \mathrm{P} / \mathrm{ppm}\right)$ for TOPO:phenol liquids as a function of composition $\left(\chi_{\mathrm{TOPO}}\right)$.

\begin{tabular}{ll}
\hline$\chi_{\text {TOPO }}$ & $\delta^{31} \mathrm{P} / \mathrm{ppm}$ \\
\hline 0.10 & 60.0 \\
0.20 & 58.2 \\
0.30 & 55.5 \\
0.40 & 53.0 \\
0.50 & 50.1 \\
0.60 & 49.1 \\
\hline
\end{tabular}




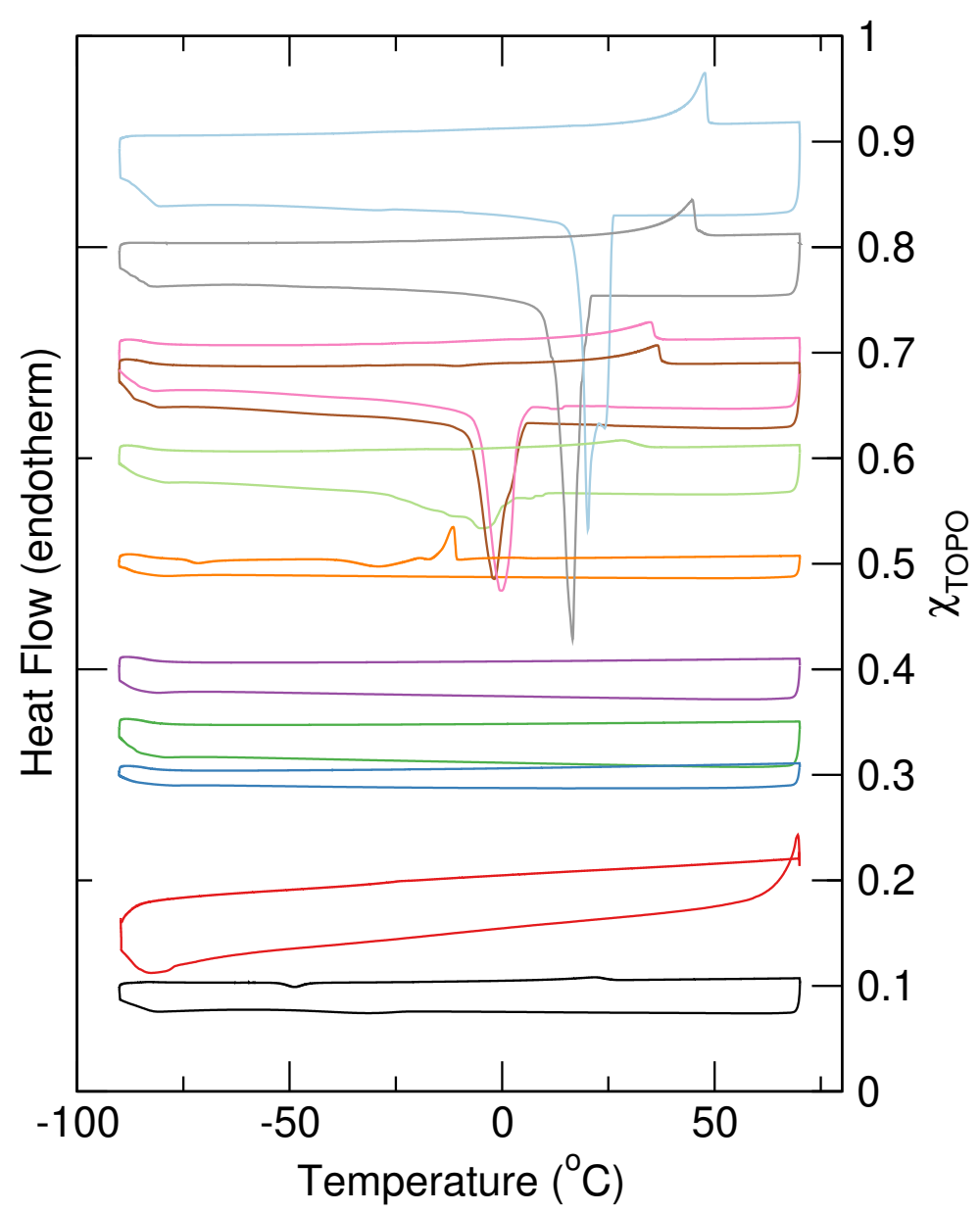

Figure 4: DSC second cooling and heating profiles for TOPO:phenol mixtures off-set from the base line by their corresponding composition $\left(\chi_{\mathrm{TOPO}}\right)$.

${ }^{31} \mathrm{P}$ NMR spectra taken from neat liquid mixtures (at $25^{\circ} \mathrm{C}$ ) at different compositions across the phase diagram are shown in Figure 6 with the chemical shifts tabulated in Table 2. The phosphorus signal from TOPO becomes increasingly deshielded, moving downfield as the concentration of phenol in the mixtures is increased (a reduction in $\chi_{\mathrm{TOPO}}$ ) reflecting the increasing addition of the acidic hydrogen-bond component in the liquids.

Between $\chi_{\text {TOPO }}=0.60$ and 0.50 , the change in ${ }^{31} \mathrm{P}$ chemical shift is only small. Both $\chi_{\text {TOPO }}$ $=0.50$ and 0.60 liquids gave ${ }^{31} \mathrm{P}$ signals between $49-50 \mathrm{ppm}$, comparable to the value reported ${ }^{52}$ for TOPO dissolved in $\mathrm{CDCl}_{3}\left(\delta^{31} \mathrm{P}=48.48 \mathrm{ppm}\right)$, and higher than that in $\mathrm{C}_{6} \mathrm{D}_{6}\left(\delta^{31} \mathrm{P}=43.93\right.$ ppm). These data points are shown in Figure 6 for comparison. This suggests that above $\chi_{\text {TOPO }}$ $=0.50$ (1:1 TOPO:phenol), the liquids have a phosphine oxide environment that resembles that of 


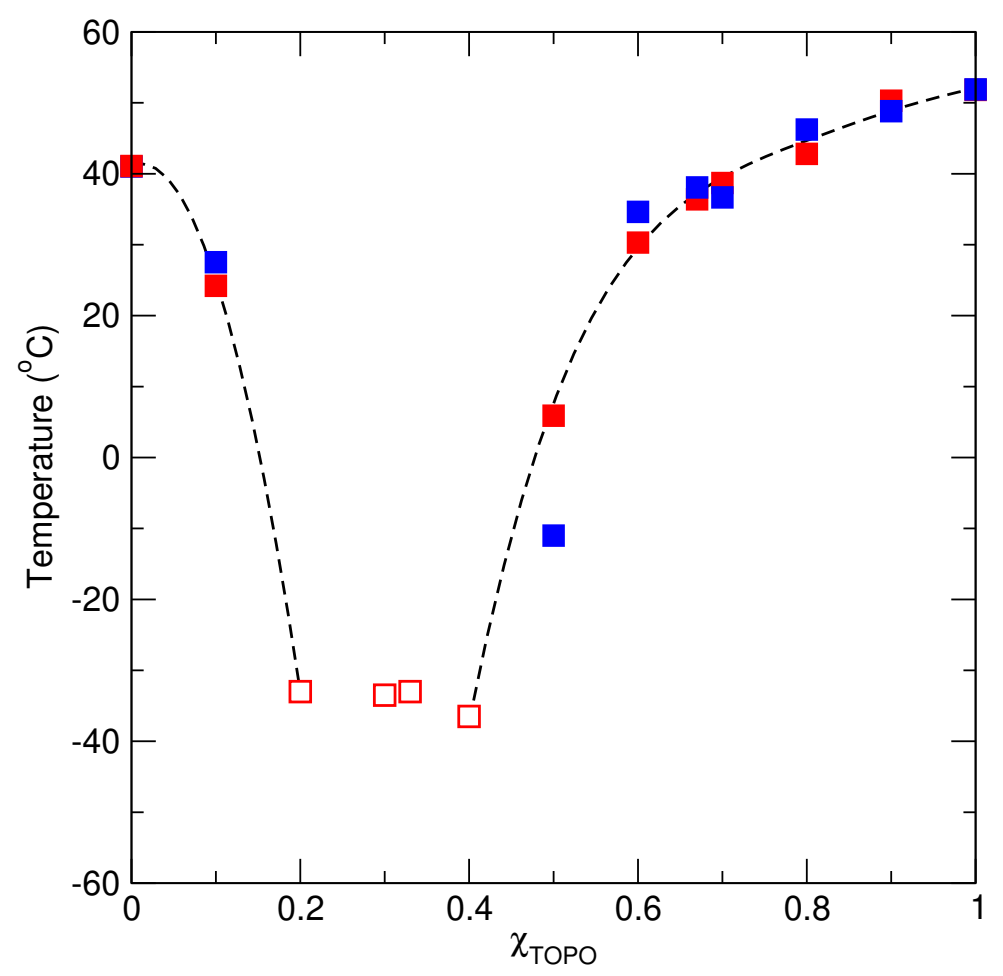

Figure 5: Phase diagram for TOPO:phenol mixture, constructed from observational solidification points (solid-liquid cell, solid red squares), and DSC results (solid blue squares) and solid-liquid cell glass transitions (open red squares).

TOPO dissolved in chloroform, and that all the phenol molecules present are involved in hydrogenbonding to single $\mathrm{P}=\mathrm{O}$ sites.

In contrast, on increasing the phenol (acid) content of the liquids (i.e. moving to lower $\chi_{\mathrm{TOPO}}$ ), the change in ${ }^{31} \mathrm{P}$ chemical shift, with the signals moving progressively downfield, reports that the phosphine oxide group is experiencing an increasingly acidic environment. However $\Delta \delta{ }^{31} \mathrm{P}$ remains approximately constant suggesting that as additional phenol is added, over the range $\chi_{\mathrm{TOPO}}=0.5-0.2$, it contributes directly to changes to the local TOPO environment. In the solid state, trialkylphosphine oxides tend to form two hydrogen-bonds in co-crystals ${ }^{53}$ and it is likely that the observed eutectic minimum around $\chi_{\mathrm{TOPO}}=0.33$ (2:1 phenol:TOPO stoicheometry) reflects this maximum number of hydrogen-bonding interactions in the liquid mixtures. however, unlike static hydrogen-bonding enabling solid-state co-crystal formation, the dynamic nature of hydrogen-bonds here probably lead to disruptively competition with lattice packing forces to induce the liquid formation. 

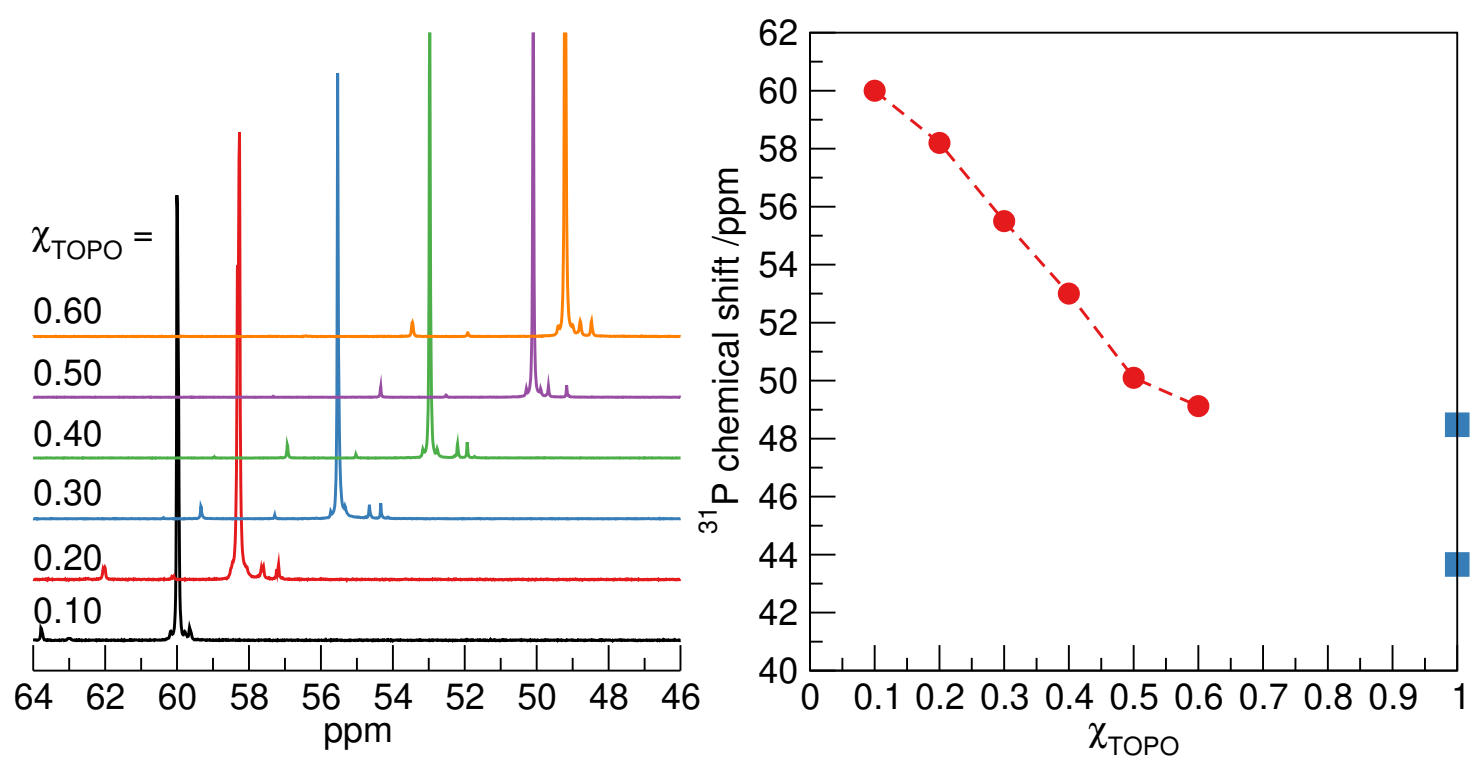

Figure 6: ${ }^{31} \mathrm{P}$ NMR spectra of TOPO:phenol liquids (left) and the corresponding chemical shift plotted as a function of liquid composition (right). Chemical shifts ${ }^{52}$ for TOPO in $\mathrm{CDCl}_{3}$ (43.66 $\mathrm{ppm}$ ) and in $\mathrm{C}_{6} \mathrm{D}_{6}(48.48 \mathrm{ppm})$ are shown at $\chi_{\mathrm{TOPO}}=1$ (blue squares) for comparison.

It is worth noting that these changes in chemical shift $\left(\Delta \delta{ }^{31} \mathrm{P}=10-11\right)$ are much smaller than have been observed for interactions of TOPO with Lewis acid metal salts forming, for example, liquid coordination complexes ${ }^{29}$ or when TOPO coordinates to hydrated protons, ${ }^{54}$ where the ${ }^{31} \mathrm{P}$ chemical shifts have been reported to change by up to nearly $40 \mathrm{ppm}$.

\section{Density and viscosity}

Densities and viscosity of the $\chi_{\mathrm{TOPO}}=0.33$ (eutectic) and 0.50 (equimolar) liquids were measured between $20-90{ }^{\circ} \mathrm{C}$ to explore the eutectic composition with the largest liquid range and to characterize a liquid composition with a higher TOPO content that could be used for liquid-liquid extraction studies. Density and viscosity results are shown in table 3 and Figure 7 and 8 .

The densities of both compositions $\left(0.935 \mathrm{~g} \mathrm{~cm}^{-3}\right.$ for $\chi_{\mathrm{TOPO}}=0.33$ at $20{ }^{\circ} \mathrm{C}$, and $0.910 \mathrm{~g} \mathrm{~cm}^{-3}$ for $\chi_{\mathrm{TOPO}}=0.50$ ) are less than that of water and decrease monotonically with increasing temperature. The density also decreases with increasing TOPO content, consistent with the differences in density of phenol and TOPO (1.07 and $0.88 \mathrm{~g} \mathrm{~cm}^{-3}$ respectively). The volume expansion coefficient of $c a .6 .75 \times 10^{-4} \mathrm{~cm}^{3} \mathrm{~K}^{-1}$ is consistent with fluid expansion from liquids containing a large 
hydrocarbon component, in this case the octyl-groups on TOPO.

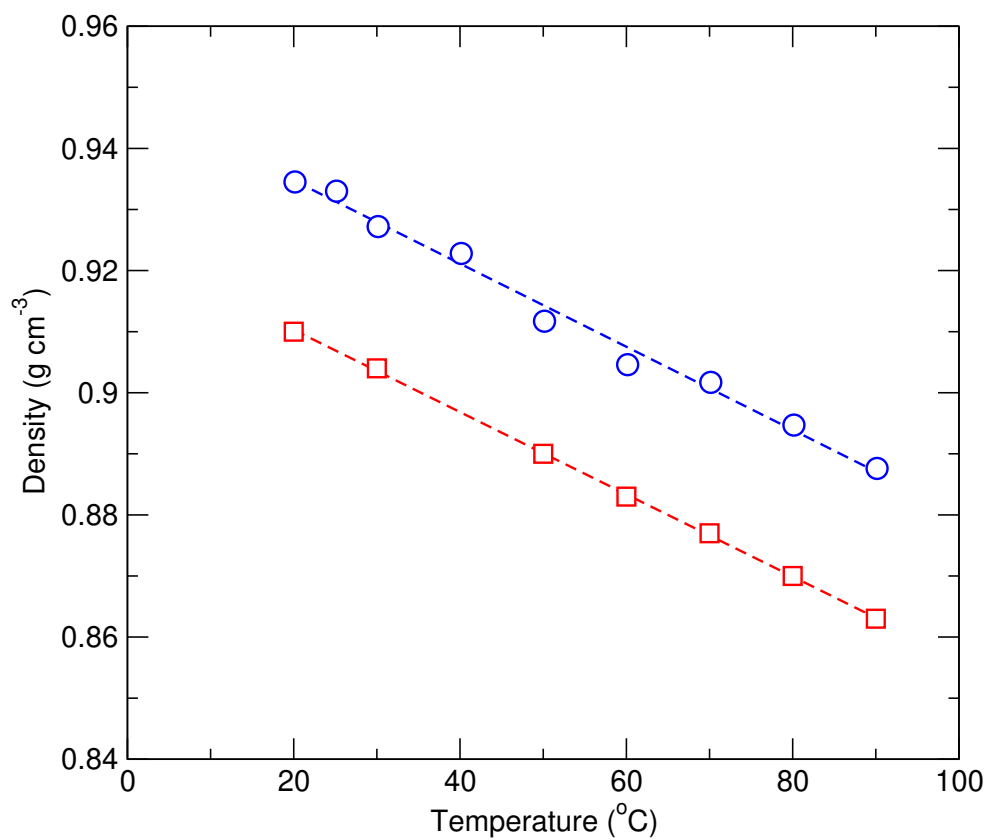

Figure 7: Density of TOPO:phenol liquids at $\chi_{\mathrm{TOPO}}=0.33$ (blue circle) and 0.50 (red square) showing the linear change in density with temperature, fitted as a function of temperature to $y=$ $1.1342-0.00068067 x\left(\chi_{\mathrm{TOPO}}=0.33\right)$ and $y=1.1075-0.00067319 x\left(\chi_{\mathrm{TOPO}}=0.50\right)$. Density of the TOPO:phenol mixtures decreases with increasing TOPO content.

The viscosity of both the dry $\chi_{\mathrm{TOPO}}=0.33$ and 0.50 TOPO:phenol liquids are much lower than those of conventional DES containing organic salt components ${ }^{55}$ and are over an order of magnitude lower than that of the $\left[\mathrm{N}_{8888}\right] \mathrm{Br}$-decanoic acid $\operatorname{DES}\left(\chi_{\left[\mathrm{N}_{8888}\right] \mathrm{Br}}=0.33\right),{ }^{22}$ which was reported as $636.36 \mathrm{mPa} \mathrm{S}$ at $25^{\circ} \mathrm{C}$. For the eutectic TOPO:DES composition $\left(\chi_{\mathrm{TOPO}}=0.33\right)$ the viscosity was $12.4 \mathrm{mPa} \mathrm{S}$ at $25^{\circ} \mathrm{C}$, similar to that of emerging non-ionic fatty acid eutectic liquid mixtures described by Florindo et al. ${ }^{28}$ and ethylene glycol $\left(16.1 \mathrm{mPa} \mathrm{S}\right.$ at $\left.25^{\circ} \mathrm{C}\right)$. Viscosity decreases with increasing temperature and was fitted with the Vogel-Fulcher-Tammann (VFT) model ${ }^{56}$ for glass forming liquids. An extrapolated glass transition temperature $\left(T_{0}\right)$ of $209 \mathrm{~K}$ was obtained.

As more TOPO is added, viscosity (and the solidification temperature) increase, but still remain low. At $\chi_{\text {TOPO }}=0.50$, the viscosity at $25{ }^{\circ} \mathrm{C}$ is $42 \pm 0.5 \mathrm{mPa} \mathrm{S}$ (Figure 8). Interestingly, this composition has characteristics that are remarkably similar to those of Cyanex $923,{ }^{45}$ which has a reported viscosity of $40 \mathrm{mPaS}$ at $25^{\circ} \mathrm{C}$ and $13.7 \mathrm{mPa} \mathrm{S}$ at $50{ }^{\circ} \mathrm{C}$, and a freezing point of -5 to $0{ }^{\circ} \mathrm{C}$. 


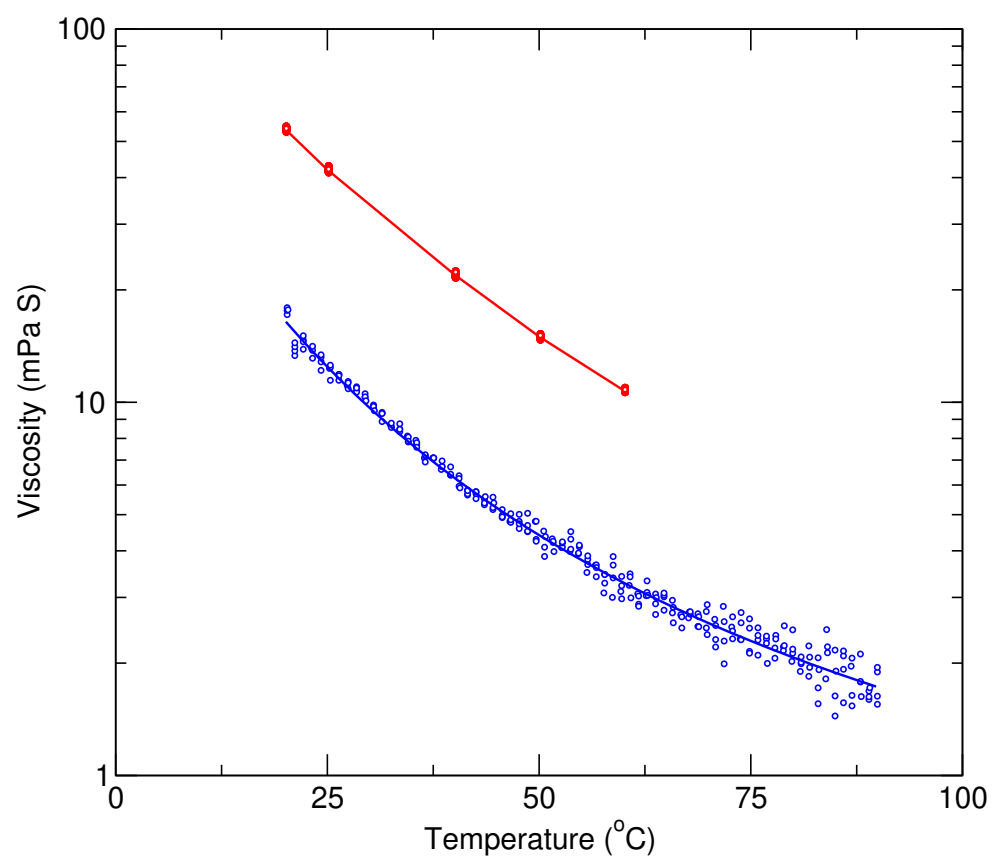

Figure 8: Viscosity of the TOPO:phenol liquids at $\chi_{\mathrm{TOPO}}=0.33$ (blue) and 0.50 (red) plotted as a function of temperature. Data at $\chi_{\text {TOPO }}=0.33$ was fitted to the Vogel-Fulcher-Tammann (VFT) equation, $v=A \times e^{\left(B / T-T_{0}\right)}$, where $v$ is viscosity $(\mathrm{mPa} \mathrm{S}), T$ is temperature $(\mathrm{K})$ and $T_{0}$ is the ideal glass transition temperature $(\mathrm{K})$ with parameters of $\ln (A)=-5.234, B=435$ and $T_{0}=209 \mathrm{~K}\left(\mathrm{r}^{2}=\right.$ 0.994568).

\section{Miscibility of TOPO:phenol $\left(\chi_{\text {TOPO }}=0.50\right)$ with water}

The ability to readily liquefy TOPO, forming mixtures with relatively wide liquid ranges and visibly low viscosity are encouraging features. Furthermore, the ambient temperature liquid TOPO:phenol mixtures all formed liquid-liquid biphases when contacted with water, suggesting that they could be used as a hydrophobic phase in liquid-liquid extraction. The stability of these liquids to aqueous acid was examined. No TOPO was detected in aqueous hydrochloric acid solutions, this is consistent with the very low TOPO solubility in water of $0.15 \mathrm{mg} \mathrm{L}^{-1} .57,58$

In contrast phenol was detected in the aqueous phases after contacting the 0.50 mole fraction TOPO:phenol eutectic with aqueous acid across a range of concentrations $(0.04-3.00 \mathrm{M} \mathrm{HCl})$ and the results are shown in table 4 . The aqueous phenol concentration after contact is low in all cases (1.10-1.34 $\left.\mathrm{g} \mathrm{L}^{-1}\right)$ compared to the high solubility of phenol in water $\left(82 \mathrm{~g} \mathrm{~L}^{-1}\right)^{59}$ and shows that phenol is preferentially concentrated in the liquid eutectic TOPO phase, with distribution ratios of 
Table 3: Density and Viscosity of TOPO:phenol mixtures at $\chi_{\mathrm{TOPO}}=0.33$ and 0.50 .

\begin{tabular}{|c|c|c|c|c|}
\hline \multirow[b]{2}{*}{$\begin{array}{l}\text { Temperature } \\
/{ }^{\circ} \mathrm{C}\end{array}$} & \multicolumn{2}{|c|}{$\chi_{\mathrm{TOPO}}=0.33$} & \multicolumn{2}{|c|}{$\chi_{\mathrm{TOPO}}=0.50$} \\
\hline & $\begin{array}{l}\text { Density } \\
/ \mathrm{g} \mathrm{cm}^{-3}\end{array}$ & $\begin{array}{l}\text { Viscosity } \\
/ \mathrm{mPa} \mathrm{s}\end{array}$ & $\begin{array}{l}\text { Density } \\
/ \mathrm{g} \mathrm{cm}^{-3}\end{array}$ & $\begin{array}{l}\text { Viscosity } \\
/ \mathrm{mPa} \mathrm{s}\end{array}$ \\
\hline 20 & 0.935 & 16.47 & 0.910 & 54.00 \\
\hline 25 & 0.933 & 12.38 & & 43.00 \\
\hline 30 & 0.927 & 9.52 & 0.904 & \\
\hline 40 & 0.923 & 6.18 & & 22.00 \\
\hline 50 & 0.912 & 4.35 & 0.890 & 15.02 \\
\hline 60 & 0.905 & 3.24 & 0.883 & 10.76 \\
\hline 70 & 0.902 & 2.53 & 0.877 & \\
\hline 80 & 0.895 & 2.04 & 0.870 & \\
\hline 90 & 0.888 & 1.73 & 0.863 & \\
\hline
\end{tabular}

Table 4: Concentration of phenol leached to aqueous acid after contacting with an equal volume of the TOPO:phenol eutectic $\left(\chi_{\text {TOPO }}=0.5\right)$ at $25^{\circ} \mathrm{C}$. Phenol solubility in water is $82 \mathrm{~g} \mathrm{~L}^{-1} .59$

\begin{tabular}{lll}
\hline $\begin{array}{l}\text { Aqueous phase } \\
/ \mathrm{M} \mathrm{HCl}\end{array}$ & \multicolumn{2}{c}{$\left[\mathrm{phenol}_{\mathrm{aq}} \begin{array}{l}\text { after contact } \\
/ \mathrm{g} \mathrm{L}^{-1}\end{array}\right.$} \\
\hline $\mathrm{mol} \mathrm{L}^{-1}$
\end{tabular}


phenol to the TOPO eutectic in the order of $D=75$.

This indicates that the liquefied TOPO could be used as an extractant for phenol from aqueous media, consistent with the reported applications of solvent-less extraction using TOPO-impregnated membranes ${ }^{42,43}$ which is likely to be facilitated by the formation of a supported eutectic liquid. This also, intriguingly, raises the possibility to form hydrophobic eutectic liquids with other acidic hydrogen-bond donors such as the carboxylic acids that have been targeted for extraction from fermentation broths ${ }^{38-41,60}$ using TOPO and also for parallel formation for hydrophobic eutectic liquids. ${ }^{22,23,26-28}$

\section{Liquid-liquid extraction studies}

The utility of these hydrophobic TOPO:phenol mixtures for liquid-liquid separations was tested using extraction of U(VI) from model acidic aqueous uranyl nitrate solutions as an example.

TOPO has been used as an effective extractant for many metals, and phosphine oxides are ubiquitous components in many extraction processes for both primary processing of nuclear materials and radioactive waste treatment ${ }^{61}$ including the commercial TRUEX and TRPO processes. ${ }^{62}$ Usu- $^{-}$ ally TOPO is used in a hydrocarbon diluent such as kerosene ${ }^{63}$ although the solubility limit of pure TOPO in kerosene of around $0.1-0.2 \mathrm{~mol} \mathrm{dm}^{-3}$ restricts the extractant concentrations that can be achieved. ${ }^{44}$ Recently the use of ionic liquid solvents for phosphine oxide-assisted partitioning of $\mathrm{U}(\mathrm{VI})$ has also been reported, ${ }^{64,65}$ building on earlier studies using hydrophobic ionic liquids as solvents for actinides and lanthanides. ${ }^{66-69}$

A significant difference between TOPO dissolved in kerosene (with relatively low solubility limit $)$ and the TOPO:phenol $\left(\chi_{\mathrm{TOPO}}=0.50\right)$ examined here as an extracting phase is the high TOPO content of $c a .80 \mathrm{wt} \%\left(1.875 \mathrm{~mol} \mathrm{~L}^{-1}\right)$. With this high concentration of TOPO, we would anticipate a high extraction ratio comparable to that reported for TRPO process using mixed trialkylphosphine oxides (equivalent to Cyanex 923) at $30 \mathrm{wt} \%$ in kerosene.

Uranyl extraction from acidic aqueous uranyl nitrate solutions was examined, contacting $1 \mathrm{~cm}^{3}$ 
Table 5: Performance of TOPO:phenol $\left(\chi_{\mathrm{TOPO}}=0.50\right)$ as a liquid extractant for uranyl nitrate from nitric acid at at different acid and uranyl concentration in the aqueous feed.

\begin{tabular}{lll}
\hline $\begin{array}{l}\text { Feed acidity } \\
(\mathrm{M})\end{array}$ & $\begin{array}{l}{\left[\mathrm{UO}_{2}{ }^{2+}\right]_{\text {init }}} \\
/ \mathrm{ppm}\end{array}$ & $\begin{array}{l}{\left[\mathrm{UO}_{2}{ }^{2+}\right]_{\text {final }}} \\
/ \mathrm{ppm}\end{array}$ \\
\hline 0.01 & 250 & $<0.50$ \\
1.00 & 250 & $<0.50$ \\
3.00 & 250 & $<0.50$ \\
1.00 & 2350 & $<0.50$ \\
\hline
\end{tabular}

$1 \mathrm{~cm}^{3}$ TOPO:phenol $\left(\chi_{\text {TOPO }}=0.50\right)$ was pre-equilibrated with nitric acid solution, and then contacted with $1 \mathrm{~cm}^{3}$ of a uranyl-containing feed (shaken, $10 \mathrm{~min}$, ambient temperature) and separated by centrifuging.

of TOPO:phenol $\left(\chi_{\mathrm{TOPO}}=0.50\right.$, pre-equilibrated against the corresponding aqueous nitric acid solutions) with $1 \mathrm{~cm}^{3}$ of uranyl-containing feeds (shaken, $10 \mathrm{~min}$, ambient temperature) with uranyl nitrate concentrations of 250 and $2350 \mathrm{ppm}$ in nitric acid (0.01-3.00 M). The final concentrations of $\mathrm{U}(\mathrm{VI})$ in the aqueous acid after extraction was determed by UV-Vis spectroscopic analysis after addition of 2-(5-bromo-2-pyridylazo)-5-(diethylamino)phenol (Br-PADAP) as the spectroscopic probe. $^{46}$

UV-Vis spectra of 5-50 ppm standards and the $250 \mathrm{ppm}$ acidic uranyl nitrate stock solution before and after contact with the TOPO:phenol extractant are shown in Figure 9) along with a picture showing the appearance of each sample. Analysis was based on the absorbance maxima at 545 and $578 \mathrm{~nm}$ in the UV-Vis spectra of uranyl-containing samples spiked with Br-PADAP indicator (Figure 9) and the detection limit for $\mathrm{U}(\mathrm{VI})$ estimated to be $0.50 \mathrm{ppm}$. The distinctive deep purple of the U(VI)-complexed Br-PADAP indicator at $250 \mathrm{ppm}$ uranyl concentration, corresponding to the intense maxima in the UV-Vis spectrum at $578 \mathrm{~nm}$, decreases markedly as the uranyl concentration in the solution decreases.

Single contact mixing of uranyl solutions (250 ppm) in 0.01, 1.00 and $3.00 \mathrm{M}$ nitric acid with the TOPO:phenol $\left(\chi_{\text {TOPO }}=0.50\right)$ liquid extractant resulted in reduction in uranyl concentrations in the raffinate phase from $250 \mathrm{ppm}$ to the detection limit for the measurements in the experiments (Table 5). The color and UV-vis spectra of raffinate solutions (spiked with Br-PADAP) after contact with TOPO:phenol was comparable to that of the blank acidic Br-PADAP solution.

When the uranyl concentration was increased ten-fold to $2350 \mathrm{ppm}$ in $1.00 \mathrm{M} \mathrm{HNO}_{3}$ (the acid- 

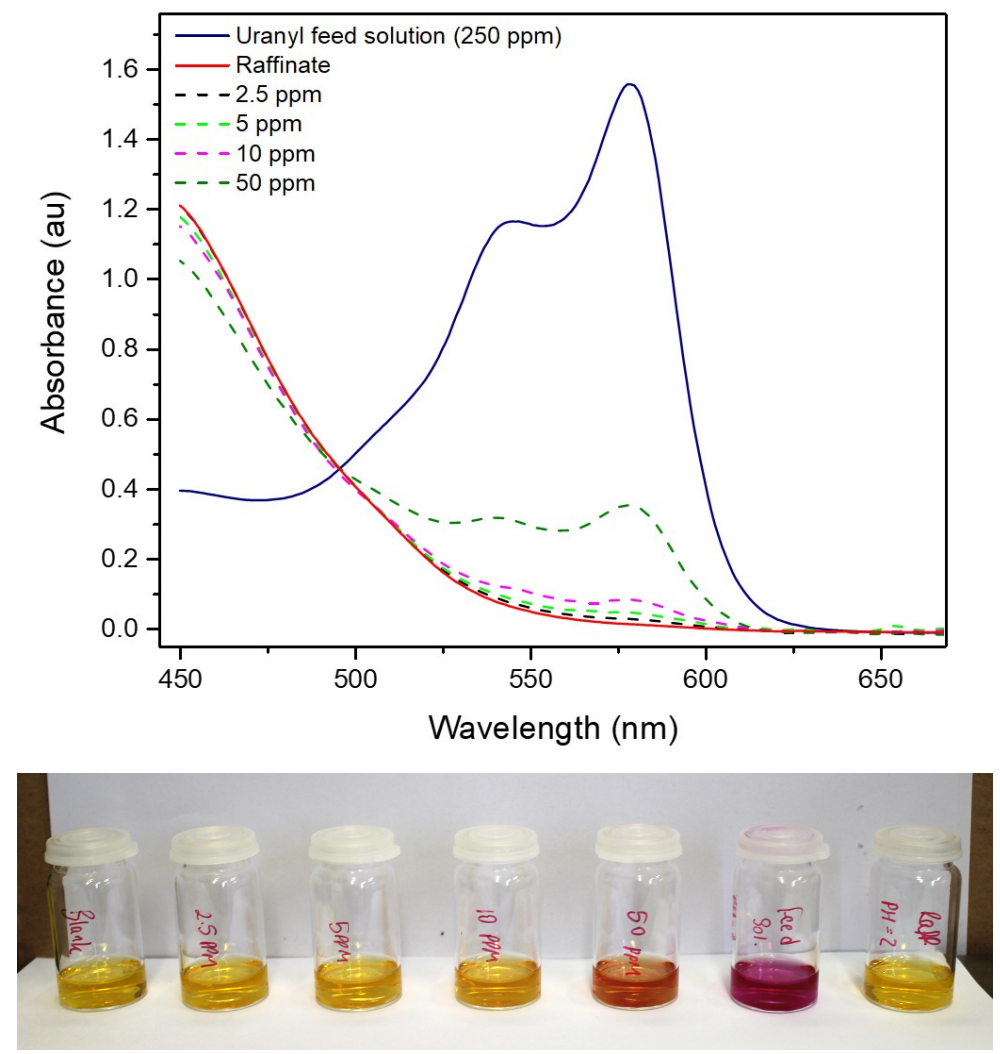

Figure 9: Transmission spectra (top) from the uranyl feed solution $\left(250 \mathrm{ppm}\left[\mathrm{UO}_{2}\right]^{2+}\right.$ ) containing Br-PADAP indicator (blue) and the raffinate after contact with TOPO:phenol (red). Standard solutions containing 5-50 ppm uranyl in nitric acid are shown as dashed lines for comparison.

ity at which TOPO has maximum efficiency) complete extraction of uranyl species was also observed suggesting that the distribution ratio could be an order of magnitude higher and demonstrating the excellent extraction potential of the TOPO:phenol system in comparison to conventional TOPO-based extraction systems. ${ }^{70-72}$

Distribution ratios could be estimated from the initial and final $\left[\mathrm{UO}_{2}\right]^{2+}$ concentrations in the aqueous phase, however because the final values are all around the limit of detection the results are unreliable. $D$ was estimated to be at least 500 from the $250 \mathrm{ppm}$ uranyl solutions, and from the $2350 \mathrm{ppm}$ solution the corresponding value is $c a$. 5000). This efficient extraction and the estimated distribution ratios are similar to values of $1 \times 10^{3}$ reported for uranium partitioning in the TRPO extraction process ${ }^{62}$ from high salt and nitric acid solutions using a complex mixture of trialkylphosphine oxides in kerosene at $30 \mathrm{wt} \%$. In the TRPO process and here, in this work, the 
origin of the high uranyl extraction efficiencies is the high concentration of phosphine oxide in the extracting phase $\left(30 \mathrm{wt} \%\right.$ for TRPO and $c a .80 \mathrm{wt} \%$ in the TOPO:phenol $\left(\chi_{\text {TOPO }}=0.50\right)$ system here, which is between 10-20 times greater than that usually used in kerosene. ${ }^{37}$

The presence of phenol does not appear to have a role in the uranyl complexation and extraction, other than as in initially generating the eutectic liquid compositions. The UV-Vis absorption spectra of uranyl nitrate $(0.05 \mathrm{M})$ dissolved in TOPO:phenol $\left(\chi_{\text {TOPO }}=0.50\right)$ and cyclohexane containing 0.30 M TOPO are shown in Figure 10. The two spectra are remarkably similar suggesting that the uranyl environments are identical in both solutions. These spectra are also comparable with previous studies from Babecki et al. ${ }^{73}$ who identified the presence of two equatorial TOPO molecules and two axial oxygens forming the extracted uranyl unit from nitric acid solution.

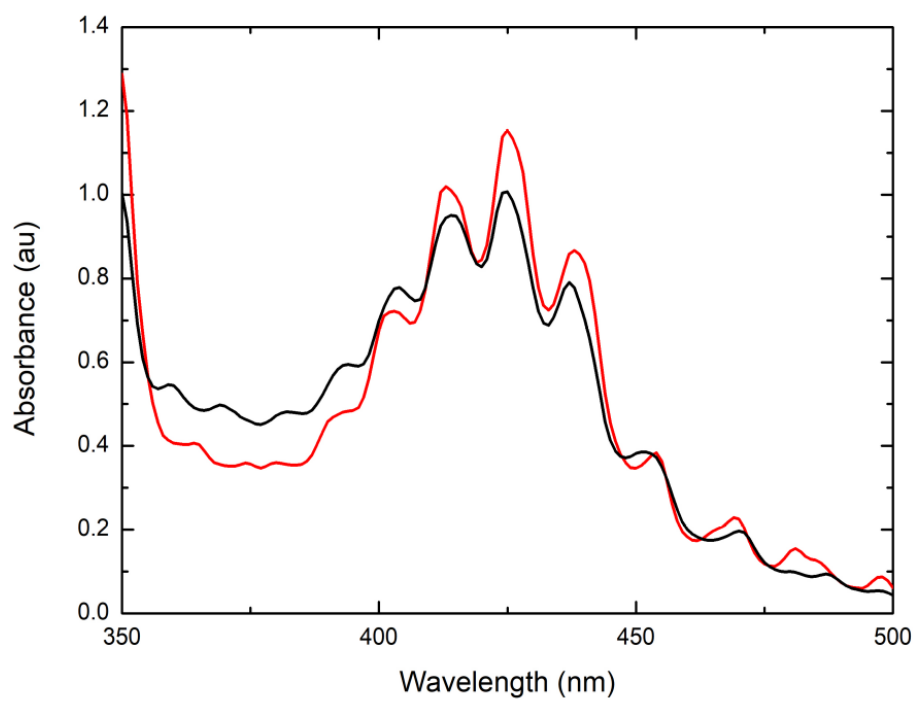

Figure 10: UV-Vis spectra for 0.05 M uranyl nitrate solutions in 0.30 M TOPO/cyclohexane (black) and $\chi_{\mathrm{TOPO}}=0.5$ TOPO:phenol (red).

Furthermore, the extraction of uranyl ions to cyclohexane containing containing TOPO, or TOPO and phenol, was comparable whereas uranyl was not extracted from $1 \mathrm{M} \mathrm{HNO}_{3}$ into cyclohexane containing only 0-2 M phenol $\left(\left[\mathrm{UO}_{2}{ }^{2+}\right]_{\text {init }}=173 \mathrm{ppm}\right.$, after contact $\left[\mathrm{UO}_{2}{ }^{2+}\right]_{\text {final }}=$ $172 \pm 3.2)$. These results support the proposition that phenol has a negligible contribution to the uranium coordination environment, and acts solely as the liquefaction component enabling formation of the TOPO-rich eutectic. 


\section{Sustainability}

The results here are the first examples from a family of new hydrophobic eutectic liquids based on TOPO using phenol here as a hydrogen-bond donor. TOPO:phenol mixtures with TOPO contents between $\chi_{\mathrm{TOPO}}=0.15-0.55$ form liquids at room temperature which have a large melting point suppression and a tend to form glasses that prevents definitive identification of the eutectic point which appears, by extrapolation, to be around $\chi_{\mathrm{TOPO}}=0.33$ (1:2 TOPO:phenol). These liquids are hydrophobic and have low viscosity (in the range $10-50 \mathrm{mPa}$ ) allowing their use as an 'organic' extraction phase for aqueous liquid-liquid extraction.

TOPO has has many applications ranging from metal ion extraction, organic acid extraction and preparation of metal chalogenide nanoparticles for use in, among many applications, biomedical imaging. ${ }^{74}$ The reported $\mathrm{LD}_{50}$ (rat, oral) for TOPO is $>2000 \mathrm{mg} \mathrm{kg}^{-1},{ }^{75}$ which is ten-times greater (less toxic) than that of Aliquat 336 (methyltrioctylammonium chloride, $\mathrm{LD}_{50}$ oral (rat) $223 \mathrm{mg} \mathrm{kg}^{-1}$ ) previously used to form hydrophobic DES. ${ }^{22,24}$ In addition, the low solubility of TOPO in water $\left(0.15 \mathrm{mg} \mathrm{L}^{-1}\right)^{57,58}$ limits bio-availability. As such, TOPO appears to be an interesting candidate to explore further to development of new hydrophobic solvents for extractions.

In comparison to the use of conventional hydrophobic organic solvents, when TOPO is required as an extractant or as a reagent (for example as a capping agent in nanocrystal synthesis), forming a DES could could lead to significant advantages through the reduction in the volumes of solvents needed as the TOPO concentrations are much greater which can aid in process intensification. For example, in the extraction of $\mathrm{U}(\mathrm{VI})$ ions from aqueous acid described here, the intrinsically high content of TOPO in the liquids, $80 \mathrm{wt} \%\left(1.875 \mathrm{~mol} \mathrm{~L}^{-1}\right)$ in the $\chi_{\mathrm{TOPO}}=0.50$ system results in liquid extractants that exhibit with high extraction efficiency with uranyl removed from the aqueous acid phase to the limit of detection and the extraction ratio was estimated to be at least $5 \times 10^{-3}$, comparable to that reported for optimized commercial TRPO process. ${ }^{62}$ This is achieved because the DES contains $c a .2 \mathrm{M}$ (>80 wt $\%$ ) of TOPO, compared to the maximum solubility below $0.5 \mathrm{M}$ in kerosene. Comparably high phosphine oxide concentrations can only be achieved by changes in the formulation (mixed phosphine oxides in Cyanex $923^{45}$ and in the TRPO process ${ }^{62}$ with 
associated greater water solubility) or by use of solvents such as dichloromethane or benzene.

However, for use in metal extraction and recovery applications, the DES described here with phenol as the hydrogen bond donor component is sub-optimal due to potential problems with

corrosivity and toxicity ${ }^{76}$ and specifically of relevance to nuclear waste processing, ${ }^{72}$ the potential to undergo nitration by concentrated nitric acid commonly used as a digestion medium. In order to address these concerns, more chemical and environmentally compatible hydrogen-bond donor components should be used, and we are exploring a range of examples including vanillin and menthol (to be reported in due course) that show comparable liquid eutectic materials. In this context, it is worth noting that menthol, considered as non-toxic, also has a reported LD50 (rat, oral) of 3,300 mg/kg, of comparable magnitude to that of TOPO.

Moreover, the generation of hydrophobic liquids on addition of phenol to solid TOPO suggests that liquefaction may have a significant rôle in the mechanism of extraction of phenol and organic carboxylic acids that can be applied to access lignin-derived phenolic platform chemicals from bio-oils ${ }^{77}$ and for the treatment of aqueous effluents from e.g. coal liquefaction, coal gasification, bio-refineries and petrochemical production using TOPO-based materials, ${ }^{38-41,44,60}$ particularly with solventless solid-supported TOPO. ${ }^{42,43}$

\section{Conclusions}

We describe the first example of a low viscosity, hydrophobic DES based on trioctylphosphine and it's application to metal extraction from aqueous acid. The high concentration of TOPO as an active extractant available in the DES enabled exceptional extraction efficiency for $\left[\mathrm{UO}_{2}\right]^{2+}$ from aqueous acid media. Modulation of aqueous solubility of phenol through preferential DES formation was also observed which reveals the possibility for application in extraction of small organic hydrogenbond donating organic molecules (phenols, alcohols, and carboxylic acids) from aqueous media through DES formation without requiring addition organic solvents. Further work in our group is focused on advancing the development of deep eutectic liquid extractants by developing analogous 
systems with hydrogen bond donors characterized by: (i) increased hydrophobicity, (ii) higher thermal stability, and (iii) synergistic extraction capabilities.

\section{Acknowledgement}

The authors thank QUILL and EPSR for studentships for MG and EM respectively, and Solvay for providing TOPO.

\section{References}

1. Zhang, Q.; De Oliveira Vigier, K.; Royer, S.; Jérôme, F. Deep eutectic solvents: syntheses, properties and applications. Chem. Soc. Rev. 2012, 41, 7108-7146, DOI: $10.1039 / \mathrm{c} 2 \mathrm{cs} 35178 \mathrm{a}$.

2. Francisco, M.; van den Bruinhorst, A.; Kroon, M. C. Low-transition-temperature mixtures (LTTMs): A new generation of designer solvents. Angew. Chem. Int. Ed. 2013, 52, 30743085, DOI: 10.1002 /anie. 201207548.

3. Smith, E. L.; Abbott, A. P.; Ryder, K. S. Deep eutectic solvents (DESs) and their applications. Chem. Rev. 2014, 114, 11060-11082, DOI: 10.1021 / cr300162p.

4. Abbott, A. P.; Boothby, D.; Capper, G.; Davies, D. L.; Rasheed, R. K. Deep eutectic solvents formed between choline chloride and carboxylic acids: versatile alternatives to ionic liquids. J. Am. Chem. Soc. 2004, 126, 9142-9147, DOI: 10.1021 / ja 048266 j.

5. Abbott, A. P.; Harris, R. C.; Holyoak, F.; Frisch, G.; Hartley, J.; Jenkin, G. R. T. Electrocatalytic recovery of elements from complex mixtures using deep eutectic solvents. Green Chem. 2015, 17, 2172-2179, DOI: 10 . 1039/c4gc02246g.

6. Gutierrez, M. C.; Carriazo, D.; Ania, C. O.; Parra, J. B.; Luisa Ferrer, M.; del Monte, F. Deep eutectic solvents as both precursors and structure directing agents in the synthesis of nitrogen 
doped hierarchical carbons highly suitable for $\mathrm{CO}_{2}$ capture. Energy Environ. Sci. 2011, 4, 3535-3544, DOI: $10.1039 / \mathrm{c} 1 \mathrm{ee} 01463 \mathrm{c}$.

7. Lopez-Salas, N.; Carriazo, D.; Gutierrez, M. C.; Ferrer, M. L.; Ania, C. O.; Rubio, F.; Tamayo, A.; Fierro, J. L. G.; del Monte, F. Tailoring the textural properties of hierarchical porous carbons using deep eutectic solvents. J. Mat. Chem. A 2016, 4, 9146-9159, DOI: $10.1039 / \mathrm{c} 6 \mathrm{ta} 02704 \mathrm{k}$.

8. Liao, H.-G.; Jiang, Y.-X.; Zhou, Z.-Y.; Chen, S.-P.; Sun, S.-G. Shape-controlled synthesis of gold nanoparticles in deep eutectic solvents for studies of structure-functionality relationships in electrocatalysis. Angew. Chem., Int. Ed. 2008, 47, 9100-9103, DOI: 10.1002 /anie.200803202.

9. Hammond, O. S.; Edler, K. J.; Bowron, D. T.; Torrente-Murciano, L. Deep eutecticsolvothermal synthesis of nanostructured ceria. Nature Comm. 2017, 8, 14150, DOI: $10.1038 /$ ncomms 14150 .

10. Hu, H.-C.; Liu, Y.-H.; Li, B.-L.; Cui, Z.-S.; Zhang, Z.-H. Deep eutectic solvent based on choline chloride and malonic acid as an efficient and reusable catalytic system for one-pot synthesis of functionalized pyrroles. RSC $A d v$. 2015, 5, 7720-7728, DOI: $10.1039 / \mathrm{c} 4 \mathrm{ra} 3577 \mathrm{f}$.

11. Liu, Y.; Friesen, J. B.; McAlpine, J. B.; Lankin, D. C.; Chen, S.-N.; Pauli, G. F. Natural deep eutectic solvents: Properties, applications, and perspectives. J. Nat. Prod. 2018, 81, 679-690, DOI: $10.1021 /$ acs.jnatprod. 7 b00945.

12. Morrison, H. G.; Sun, C. C.; Neervannan, S. Characterization of thermal behavior of deep eutectic solvents and their potential as drug solubilization vehicles. Int. J. Pharm. 2009, 378, 136-139, DOI: $10.1016 / j . i j p h a r m .2009 .05 .039$.

13. Huddleston, J.; Willauer, H.; Swatloski, R.; Visser, A.; Rogers, R. Room temperature ionic 
liquids as novel media for 'clean' liquid-liquid extraction. Chem. Commun. 1998, 1765-1766, DOI: $10.1039 / \mathrm{a} 803999 \mathrm{~b}$.

14. Huddleston, J.; Visser, A.; Reichert, W.; Willauer, H.; Broker, G.; Rogers, R. Characterization and comparison of hydrophilic and hydrophobic room temperature ionic liquids incorporating the imidazolium cation. Green Chem. 2001, 3, 156-164, DOI: 10 .1039/b103275p.

15. Gilmore, M.; Moura, L. M.; Turner, A. H.; Swadzba-Kwasny, M.; Callear, S. K.; McCune, J. A.; Scherman, O. A.; Holbrey, J. D. A comparison of choline:urea and choline:oxalic acid deep eutectic solvents at 338 K. J. Chem. Phys. 2018, 148, 193823, DOI: $10.1063 / 1.5010246$.

16. Araujo, C. F.; Coutinho, J. A. P.; Nolasco, M. M.; Parker, S. F.; Ribeiro-Claro, P. J. A.; Rudic, S.; Soares, B. I. G.; Vaz, P. D. Inelastic neutron scattering study of reline: shedding light on the hydrogen bonding network of deep eutectic solvents. Phys. Chem. Chem. Phys. 2017, 19, 17998-18009, DOI: $10.1039 /$ c7cp01286a.

17. Stefanovic, R.; Ludwig, M.; Webber, G. B.; Atkin, R.; Page, A. J. Nanostructure, hydrogen bonding and rheology in choline chloride deep eutectic solvents as a function of the hydrogen bond donor. Phys. Chem. Chem. Phys. 2017, 19, 3297-3306, DOI: 10 .1039/ c6cp07932f.

18. Hammond, O. S.; Bowron, D. T.; Edler, K. J. Liquid structure of the choline chloride-urea deep eutectic solvent (reline) from neutron diffraction and atomistic modelling. Green Chem. 2016, 18, 2736-2744, DOI: 10.1039 /c5gc02914g.

19. Ashworth, C. R.; Matthews, R. P.; Welton, T.; Hunt, P. A. Doubly ionic hydrogen bond interactions within the choline chloride-urea deep eutectic solvent. Phys. Chem. Chem. Phys. 2016, 18, 18145-18160, DOI: $10.1039 /$ c6cp02815b.

20. Wagle, D. V.; Baker, G. A.; Mamontov, E. Differential microscopic mobility of components within a deep eutectic solvent. J. Phys. Chem. Lett. 2015, 6, 2924-2928, DOI: $10.1021 /$ acs.jpclett.5b01192. 
21. Perkins, S. L.; Painter, P.; Colina, C. M. Experimental and computational studies of choline chloride-based deep eutectic solvents. J. Chem. Eng. Data 2014, 59, 3652-3662, DOI: $10.1021 /$ je500520h.

22. van Osch, D. J. G. P.; Zubeir, L. F.; van den Bruinhorst, A.; Rocha, M. A. A.; Kroon, M. C. Hydrophobic deep eutectic solvents as water-immiscible extractants. Green Chem. 2015, 17, 4518-4521, DOI: $10.1039 / \mathrm{c} 5 \mathrm{gc0} 01451 \mathrm{~d}$.

23. van Osch, D. J. G. P.; Parmentier, D.; Dietz, C. H. J. T.; van den Bruinhorst, A.; Tuinier, R.; Kroon, M. C. Removal of alkali and transition metal ions from water with hydrophobic deep eutectic solvents. Chem. Commun. 2016, 52, 11987-11990, DOI: 10 .1039/c6cc06105b.

24. Cao, J.; Yang, M.; Cao, F.; Wang, J.; Su, E. Well-designed hydrophobic deep eutectic solvents as green and efficient media for the extraction of artemisinin from artemisia annua leaves. ACS Sus. Chem. Eng. 2017, 5, 3270-3278, DOI: 10 .1021/acssuschemeng. $6 \mathrm{~b} 03092$.

25. Cao, J.; Chen, L.; Li, M.; Cao, F.; Zhao, L.; Su, E. Two-phase systems developed with hydrophilic and hydrophobic deep eutectic solvents for simultaneously extracting various bioactive compounds with different polarities. Green Chem. 2018, 20, 1879-1886, DOI: $10.1039 / \mathrm{c} 7 \mathrm{gc} 03820 \mathrm{~h}$.

26. Ribeiro, B. D.; Florindo, C.; Iff, L. C.; Coelho, M. A. Z.; Marrucho, I. M. Menthol-based eutectic mixtures: Hydrophobic low viscosity solvents. ACS Sus. Chem. Eng. 2015, 3, 2469 2477, DOI: $10.1021 /$ acssuschemeng.5b00532.

27. Martins, M. A. R.; Crespo, E. A.; Pontes, P. V. A.; Silva, L. P.; Bülow, M.; Maximo, G. J.; Batista, E. A. C.; Held, C.; Pinho, S. P.; Coutinho, J. A. P. Tunable hydrophobic eutectic solvents based on terpenes and monocarboxylic acids. ACS Sus. Chem. Eng. 2018, 6, 88368846, DOI: 10.1021 /acssuschemeng. 8b01203.

28. Florindo, C.; Romero, L.; Rintoul, I.; Branco, L. C.; Marrucho, I. M. From phase change 
materials to green solvents: Hydrophobic low viscous fatty acid-based deep eutectic solvents. ACS Sus. Chem. Eng. 2018, 6, 3888-3895, DOI: 10.1021 /acssuschemeng . 7b 04235.

29. Hogg, J. M.; Brown, L. C.; Matuszek, A.; Latos, P.; Chrobok, A.; Swadzba-Kwasny, M. Liquid coordination complexes of Lewis acidic metal chlorides: Lewis acidity and insights into speciation. Dalton Trans. 2017, 46, 11561-11574, DOI: 10 .1039/c 7 dt 02408 h.

30. Hogg, J. M.; Coleman, F.; Ferrer-Ugalde, A.; Atkins, M. P.; Swadzba-Kwasny, M. Liquid coordination complexes: a new class of Lewis acids as safer alternatives to $\mathrm{BF}_{3}$ in synthesis of polyalphaolefins. Green Chem 2015, 17, 1831-1841, DOI: $10.1039 /$ c 4 gc02080d.

31. Coleman, F.; Srinivasan, G.; Swadzba-Kwasny, M. Liquid coordination complexes formed by the heterolytic cleavage of metal halides. Angew Chem., Int Ed. 2013, 52, 12582-12586, DOI: 10.1002 /anie.201306267.

32. Mekis, I.; Talapin, D.; Kornowski, A.; Haase, M.; Weller, H. One-pot synthesis of highly luminescent $\mathrm{CdSe} / \mathrm{CdS}$ core-shell nanocrystals via organometallic and "greener" chemical approaches. J. Phys. Chem. B 2003, 107, 7454-7462, DOI: 10 . 1021/ jp0278364.

33. Mikulec, F.; Kuno, M.; Bennati, M.; Hall, D.; Griffin, R.; Bawendi, M. Organometallic synthesis and spectroscopic characterization of manganese-doped CdSe nanocrystals. J. Amer. Chem. Soc. 2000, 122, 2532-2540, DOI: $10.1021 /$ ja991249n.

34. Cassagneau, T.; Mallouk, T.; Fendler, J. Layer-by-layer assembly of thin film zener diodes from conducting polymers and CdSe nanoparticles. J. Amer. Chem. Soc 1998, 120, 78487859, DOI: $10.1021 /$ ja9806027.

35. Trindade, T.; OBrien, P.; Zhang, X. Synthesis of CdS and CdSe nanocrystallites using a novel single-molecule precursors approach. Chem. Mater. 1997, 9, 523-530, DOI: $10.1021 / \mathrm{cm} 960363 r$. 
36. Guzelian, A.; Katari, J.; Kadavanich, A.; Banin, U.; Hamad, K.; Juban, E.; Alivisatos, A.; Wolters, R.; Arnold, C.; Heath, J. Synthesis of size-selected, surface-passivated InP nanocrystals. J. Phys. Chem. 1996, 100, 7212-7219, DOI: 10.1021 / jp953719f.

37. Watson, E.; Rickelton, W. A review of the industrial and recent potential applications of trioctylphosphine oxide. Solvent Extr. Ion Exch. 1992, 10, 879-889, DOI: $10.1080 / 07366299208918141$.

38. Saboe, P. O.; Manker, L. P.; Michener, W. E.; Peterson, D. J.; Brandner, D. G.; Deutch, S. P.; Kumar, M.; Cywar, R. M.; Beckham, G. T.; Karp, E. M. In situ recovery of bio-based carboxylic acids. Green Chem. 2018, 20, 1791-1804, DOI: 10.1039 / c 7 gc 03747 C.

39. Brouwer, T.; Blahusiak, M.; Babic, K.; Schuur, B. Reactive extraction and recovery of levulinic acid, formic acid and furfural from aqueous solutions containing sulphuric acid. Sep. Purif. Technol. 2017, 185, 186-195, DOI: 10 .1016/j . seppur.2017.05.036.

40. Kim, G.-H.; Park, S.-J.; Um, B.-H. Response surface methodology for optimization of solvent extraction to recovery of acetic acid from black liquor derived from Typha latifolia pulping process. Ind. Crops Prod. 2016, 89, 34-44, DOI: $10.1016 /$ j. indcrop . 2016.04 .056$.

41. Matsumoto, M.; Uenoyama, S.; Hano, T.; Hirata, M.; Miura, S. Extraction kinetics of organic acids with tri-n-octylphosphine oxide. J. Chem. Technol. Biotechnol. 1996, 67, 260-264, DOI: $10.1002 /($ SICI) 1097-4660 (199611) 67:3<260::AID-JCTB559>3.0.CO;2-Y.

42. Praveen, P.; Loh, K.-C. Solid/liquid extraction equilibria of phenolic compounds with trioctylphosphine oxide impregnated in polymeric membranes. Chemosphere 2016, 153, 405413, DOI: $10.1016 / j . c h e m o s p h e r e .2016 .03 .053$.

43. Praveen, P.; Loh, K.-C. Trioctylphosphine oxide-impregnated hollow fiber membranes for removal of phenol from wastewater. J. Membr. Sci. 2013, 437, 1-6, DOI: $10.1016 / j . m e m s c i .2013 .02 .057$. 
44. Watson, E.; Rickelton, W.; Robertson, A.; Brown, T. A liquid phosphine oxide - solventextraction of phenol, acetic-acid and ethanol. Solvent Extr. Ion Exch. 1988, 6, 207-220, DOI: $10.1080 / 07366298808917932$.

45. CYANEX 923 Extractant - Solvent Extraction Reagent. https://www.cytec.com/ sites/default/files/datasheets/SPT-032-D.pdf.

46. Biswas, S.; Pathak, P. N.; Roy, S. B. Development of an extractive spectrophotometric method for estimation of uranium in ore leach solutions using 2-ethylhexyl phosphonic acid-mono-2ethylhexyl ester (PC88A) and tri-n-octyl phosphine oxide (TOPO) mixture as extractant and 2-(5-bromo-2-pyridylozo)-5-diethyl aminophenol (Br-PADAP) as chromophore. Spectrochim. Acta. A 2012, 91, 222-227, DOI: $10.1016 /$ j.saa.2012.02 . 005.

47. Ferguson, J. B. The system water-phenol. J. Phys. Chem. 1926, 31, 757-763, DOI: $10.1021 / j 150275 a 013$.

48. Pang, K.; Hou, Y.; Wu, W.; Guo, W.; Peng, W.; Marsh, K. N. Efficient separation of phenols from oils via forming deep eutectic solvents. Green Chem. 2012, 14, 2398-2401, DOI: $10.1039 / \mathrm{c} 2 \mathrm{gc} 35400 \mathrm{~d}$.

49. Forsyth, S.; Golding, J.; MacFarlane, D.; Forsyth, M. N-methyl-N-alkylpyrrolidinium tetrafluoroborate salts: ionic solvents and solid electrolytes. Electrochim. Acta 2001, 46, 1753-1757, DOI: $10.1016 / \mathrm{s} 0013-4686(00) 00781-7$.

50. Holbrey, J. D.; Reichert, W. M.; Swatloski, R. P.; Broker, G. A.; Pitner, W. R.; Seddon, K. R.; Rogers, R. D. Efficient, halide free synthesis of new, low cost ionic liquids: 1,3dialkylimidazolium salts containing methyl- and ethyl-sulfate anions. Green Chem. 2002, 4, 407-413, DOI: $10.1039 /$ b2 04469 b.

51. Armel, V.; Velayutham, D.; Sun, J.; Howlett, P. C.; Forsyth, M.; MacFarlane, D. R.; Pringle, J. M. Ionic liquids and organic ionic plastic crystals utilizing small phosphonium cations. J. Mater. Chem. 2011, 21, 7640-7650, DOI: 10 . 1039 / c1 jm1 0417 a. 
52. Hilliard, C. R.; Bhuvanesh, N.; Gladysz, J. A.; Bluemel, J. Synthesis, purification, and characterization of phosphine oxides and their hydrogen peroxide adducts. Dalton Trans. 2012, 41, 1742-1754, DOI: $10.1039 / \mathrm{c} 1 \mathrm{dt} 11863 \mathrm{C}$.

53. Tupikina, E. Y.; Bodensteiner, M.; Tolstoy, P. M.; Denisov, G. S.; Shenderovich, I. G. P=O moiety as an ambidextrous hydrogen bond acceptor. J. Phys. Chem. C 2018, 122, 1711-1720, DOI: $10.1021 /$ acs.jpcc. 7b11299.

54. Kriz, J.; Dybal, J.; Makrlik, E.; Budka, J.; Vanura, P. Interaction of hydrated protons with trioctylphosphine oxide: NMR and theoretical study. J. Phys. Chem. A 2009, 113, 5896-5905, DOI: $10.1021 /$ jp9012575.

55. Ruß, C.; König, B. Low melting mixtures in organic synthesis - an alternative to ionic liquids. Green Chem. 2012, 14, 2969-2982, DOI: 10 . 1039 /c2gc36005e.

56. Mauro, J. C.; Yue, Y.; Ellison, A. J.; Gupta, P. K.; Allan, D. C. Viscosity of glass-forming liquids. Proc. Nat. Ac. Sci. 2009, 106, 19780-19784, DOI: 10.1073 /pnas . 0911705106.

57. Ghersini, G. In Extraction Chromatography; Braun, T., Ghersini, G., Eds.; Journal of Chromatography Library; Elsevier, 1975; Vol. 2; pp 68-129.

58. Wardell, J. M.; King, C. J. Solvent equilibriums for extraction of carboxylic acids from water. J. Chem. Eng. Data 1978, 23, 144-148, DOI: 10.1021 / je60077a009.

59. Southworth, G. R.; Keller, J. L. Hydrophobic sorption of polar organics by low organic carbon soils. Water, Air, and Soil Pollution 1986, 28, 239-248, DOI: 10.1007 /bf 00583490.

60. Alkaya, E.; Kaptan, S.; Ozkan, L.; Uludag-Demirer, S.; Demirer, G. N. Recovery of acids from anaerobic acidification broth by liquid-liquid extraction. Chemosphere 2009, 77, 1137-1142, DOI: $10.1016 / j . c h e m o s p h e r e .2009 .08 .027$.

61. Bayliss, C.; Langley, K. Nuclear decommissioning, waste management, and environmental site remediation; Elsevier, 2003; DOI: 10 .1016/b978-0-7506-7744-8 .b5000-0. 
62. Wang, J. C.; Song, C. L. Hot test of trialkyl phosphine oxide (TRPO) for removing actinides from highly saline high-level liquid waste (HLLW). Solv. Extr. Ion Exch. 2001, 19, 231-242, DOI: $10.1081 /$ sei-100102693.

63. Krea, M.; Khalaf, H. Liquid-liquid extraction of uranium and lanthanides from phosphoric acid using a synergistic DOPPA-TOPO mixture. Hydromet. 2000, 58, 215-225, DOI: $10.1016 / \mathrm{s} 0304-386 \times(00) 00129-8$.

64. Yuan, L. Y.; Sun, M.; Liao, X. H.; Liang, Z. Y.; Fang, C. Z.; Qun, S. W. Solvent extraction of U(VI) by trioctylphosphine oxide using a room-temperature ionic liquid. Science Chin.-Chem. 2014, 57, 1432-1438, DOI: 10.1007 /s11426-014-5194-8.

65. Rout, A.; Binnemans, K. Influence of the ionic liquid cation on the solvent extraction of trivalent rare-earth ions by mixtures of Cyanex 923 and ionic liquids. Dalton Trans. 2015, 44, 1379-1387, DOI: $10.1039 /$ c4dt 02766 c.

66. Prabhu, D. R.; Mohapatra, P. K.; Raut, D. R.; Pathak, P.; Billard, I. Extraction of uranium(VI) from nitric acid solutions using N,N-dihexyloctanamide in ionic liquids: Solvent extraction and spectroscopic studies. Solvent Extr. Ion Exch. 2017, 35, 423-438, DOI: $10.1080 / 07366299.2017 .1377423$.

67. Gaillard, C.; Boltoeva, M.; Billard, I.; Georg, S.; Mazan, V.; Ouadi, A. Ionic liquid-based uranium(VI) extraction with malonamide extractant: cation exchange vs. neutral extraction. RSC Adv. 2016, 6, 70141-70151, DOI: 10.1039 / c6ra11345a.

68. Cocalia, V.; Jensen, M.; Holbrey, J.; Spear, S.; Stepinski, D.; Rogers, R. Identical extraction behavior and coordination of trivalent or hexavalent f-element cations using ionic liquid and molecular solvents. Dalton Trans. 2005, 1966-1971, DOI: 10.1039 /b502016f.

69. Barber, P. S.; Kelley, S. P.; Rogers, R. D. Highly selective extraction of the uranyl ion with hydrophobic amidoxime-functionalized ionic liquids via $\eta^{2}$ coordination. $R S C A d v . \mathbf{2 0 1 2}, 2$, 8526-8530, DOI: $10.1039 /$ c2ra21344c. 
70. Mohapatra, P. K.; Raut, D. R.; Sengupta, A. Extraction of uranyl ion from nitric acid medium using solvent containing TOPO and its mixture with D2EHPA in room temperature ionic liquids. Sep. Pur. Technol. 2014, 133, 69-75, DOI: $10.1016 /$ j . seppur. 2014.06 .033$.

71. Bunus, F.; Domocos, V.; Dumitrescu, P. Synergic extraction of uranium from phosphate solutions with di-(2-ethylhexyl) phosphoric acid and tri-n-octylphosphine oxide. J. Inorg. Nucl. Chem. 1978, 40, 117-121, DOI: $10.1016 / 0022-1902$ ( 78 ) 80318-2.

72. Sato, T.; Nishida, T.; Yamatake, M. Extraction of uranium (VI) and thorium (IV) from nitricacid solutions by tri-n-octyl phosphine oxide. J. Appl. Chem. Biotechnol. 1973, 23, 909-917, DOI: $10.1002 /$ jctb. 5020231209 .

73. Babecki, R.; Platt, A.; Tebby, J.; Fawcett, J.; Russell, D.; Little, R. The crystal and molecular-structure of $\mathrm{UO}_{2}\left(\mathrm{NO}_{3}\right)_{2}\left[\mathrm{PH}_{2} \mathrm{P}(\mathrm{O}) \mathrm{CH}_{2} \mathrm{C}(\mathrm{O}) \mathrm{PH}\right]_{2}$ and its role in the solvent extraction of the uranyl-ion. Polyhedron 1989, 8, 1357-1360, DOI: $10.1016 / \mathrm{s} 0277-5387(00) 86536-5$.

74. Pinaud, F.; King, D.; Moore, H.; Weiss, S. Bioactivation and cell targeting of semiconductor $\mathrm{CdSe} / \mathrm{ZnS}$ nanocrystals with phytochelatin-related peptides. J. Amer. Chem. Soc. 2004, 126, 6115-6123, DOI: 10.1021 / ja031691c.

75. SigmaAldrich Chemical SDS. https://www.sigmaaldrich.com/ safety-center.html.

76. Babich, H.; Davis, D. Phenol: A review of environmental and health risks. Regulatory Toxicology and Pharmacology 1981, 1, 90-109, DOI: $10.1016 / 0273-2300$ (81) 90071-4.

77. Xiao, L.-P.; Wang, S.; Li, H.; Li, Z.; Shi, Z.-J.; Xiao, L.; Sun, R.-C.; Fang, Y.; Song, G. Catalytic hydrogenolysis of lignins into phenolic compounds over carbon nanotube supported molybdenum oxide. ACS Catalysis 2017, 7, 7535-7542, DOI: 10.1021 /acscatal. 7b02563. 


\section{Synopsis}

Advanced hydrophobic, solvent-free liquid extractants can be prepared by combination of trioctylphosphine oxide with suitable hydrogen-bond donors.

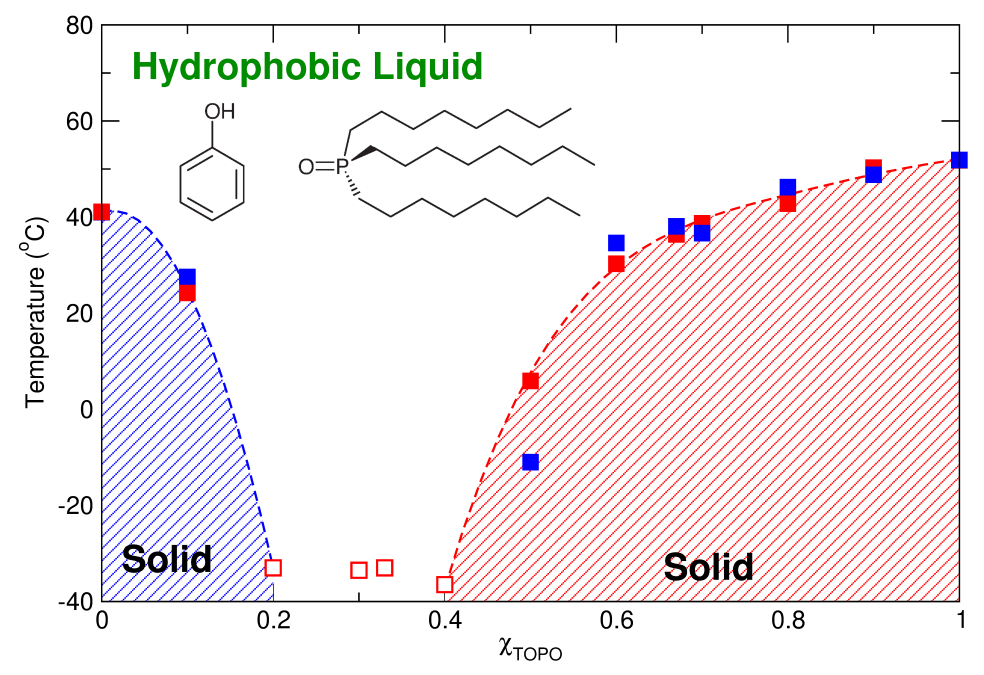

